Article

\title{
Water Isotopes as Environmental Tracers for Conceptual Understanding of Groundwater Flow: An Application for Fractured Aquifer Systems in the "Scansano-Magliano in Toscana" Area (Southern Tuscany, Italy)
}

\author{
Marco Doveri * and Mario Mussi \\ National Research Council of Italy, Institute of Geosciences and Earth Resources, \\ Via G. Moruzzi 1 56124, Pisa, Italy; E-Mail: igg@igg.cnr.it \\ * Author to whom correspondence should be addressed; E-Mail: doveri@igg.cnr.it; \\ Tel.: +39-050-621-2321; Fax: +39-050-621-2323
}

Received: 7 May 2014; in revised form: 2 July 2014 / Accepted: 10 July 2014 /

Published: 31 July 2014

\begin{abstract}
The "Scansano-Magliano in Toscana" area is characterized by a morpho-structure chiefly made-up by sandstone and shelly-calcareous lithologies. Generally, these complexes host minor aquifers in Tuscany, since they have medium to medium-low permeability. In the area under examination, a sandstone outcrop develops with continuity along the ridge of the structure for several kilometers and above a shelly substratum. Consequently, this hydrostructural context suggested the possibility that a significant groundwater body was hosted in the sandstones. In order to verify this assumption, an isotopic study was carried out taking into account several wells and springs sited on the sandstone outcrop and its surrounding area; the samples collected over a period of two years were analyzed to obtain $\delta^{18} \mathrm{O} \%$, $\delta^{2} \mathrm{H} \%$ and ${ }^{3} \mathrm{H}$. A study of the hydrostructural and morphological condition was also performed, and minor springs were selected. The analyses of this spring-water resulted in the characterization of the isotopic features of the infiltration water in the studied area, which represents a fundamental base of work for the interpretation of the data of groundwater points which drain long flow paths. By means of this approach, the groundwater framework was defined and the presence of a significant and continuous groundwater body within the sandstone complex was verified. A preliminary conceptual hydrogeological model was also proposed.
\end{abstract}


Keywords: groundwater exploration; groundwater flow systems; fractured aquifer; environmental tracer; water isotopes; Italy

\section{Introduction}

Water isotopes in hydrogeology act as real natural tracers because their signatures are not affected by water-rock interaction processes up to temperatures of about $200{ }^{\circ} \mathrm{C}$ [1]. Their main properties, such as the variation of values in rainfall both over the different periods of the year and with the altitude of precipitation [2-4], can consequently be used to define several aspects of the groundwater flow. By analyzing the ratios ${ }^{18} \mathrm{O} /{ }^{16} \mathrm{O},{ }^{2} \mathrm{H} /{ }^{1} \mathrm{H}$ and ${ }^{3} \mathrm{H}$ in springs and/or in water collected from wells, it is possible to: (i) highlight the existence of different groundwater systems, even when these have same chemical features; (ii) evaluate the recharge average altitude of groundwater systems; (iii) achieve information about the hydrodynamic conditions in the aquifer and so on the groundwater vulnerability; (iv) achieve information about the groundwater residence time.

In fractured and/or karst aquifers, the water isotopes usefulness may be enhanced by the considerable range of altitude in which these systems normally develop and by the strong heterogeneity of hydraulic properties that affects isotopic ratios in groundwater, both in space and in time. As shown by several works of literature (e.g., [5-8]), isotopic applications are a fundamental tool for groundwater flow understanding in such hydrogeological systems.

In this paper, a study mainly based on water isotopes is discussed in order to make observations, as this kind of survey is able to point out if groundwater framework is characterized by propitious conditions for water supplying, such as the presence of extensive groundwater bodies. In particular, the research was carried out on a sandstone aquifer that runs for more than $10 \mathrm{~km}$ along the Scansano-Magliano in Toscana ridge, in southern Tuscany (Figure 1). Few hydrogeological data are available for this area, because of the lack of previous studies. Nevertheless, the hydrostructural framework suggests that such fractured aquifer might be a strategic and alternative resource for water supply, also taking into account the overexploitation and contamination of the nearby alluvial aquifers. Despite the sandstone is characterized by medium to medium-low permeability and the wells therein generally have flow rates of a few liters per second, given its extension it can hold a large volume of water, which might be tapped by a multiple well solution once verified the presence of a continuity of groundwater circulation. In this context, several springs and wells were sampled in the Scansano-Magliano in Toscana zone and its surrounding areas, and analyses of $\delta^{18} \mathrm{O} \%$, $\delta^{2} \mathrm{H} \%$ and ${ }^{3} \mathrm{H}$ were performed, with the aim to define the groundwater framework and to identify the main groundwater flow systems, thus verifying whether propitious conditions exist to improve the water supply of the area. 
Figure 1. Geological sketch map and distribution of sampled water points (geological data from [9], modified).

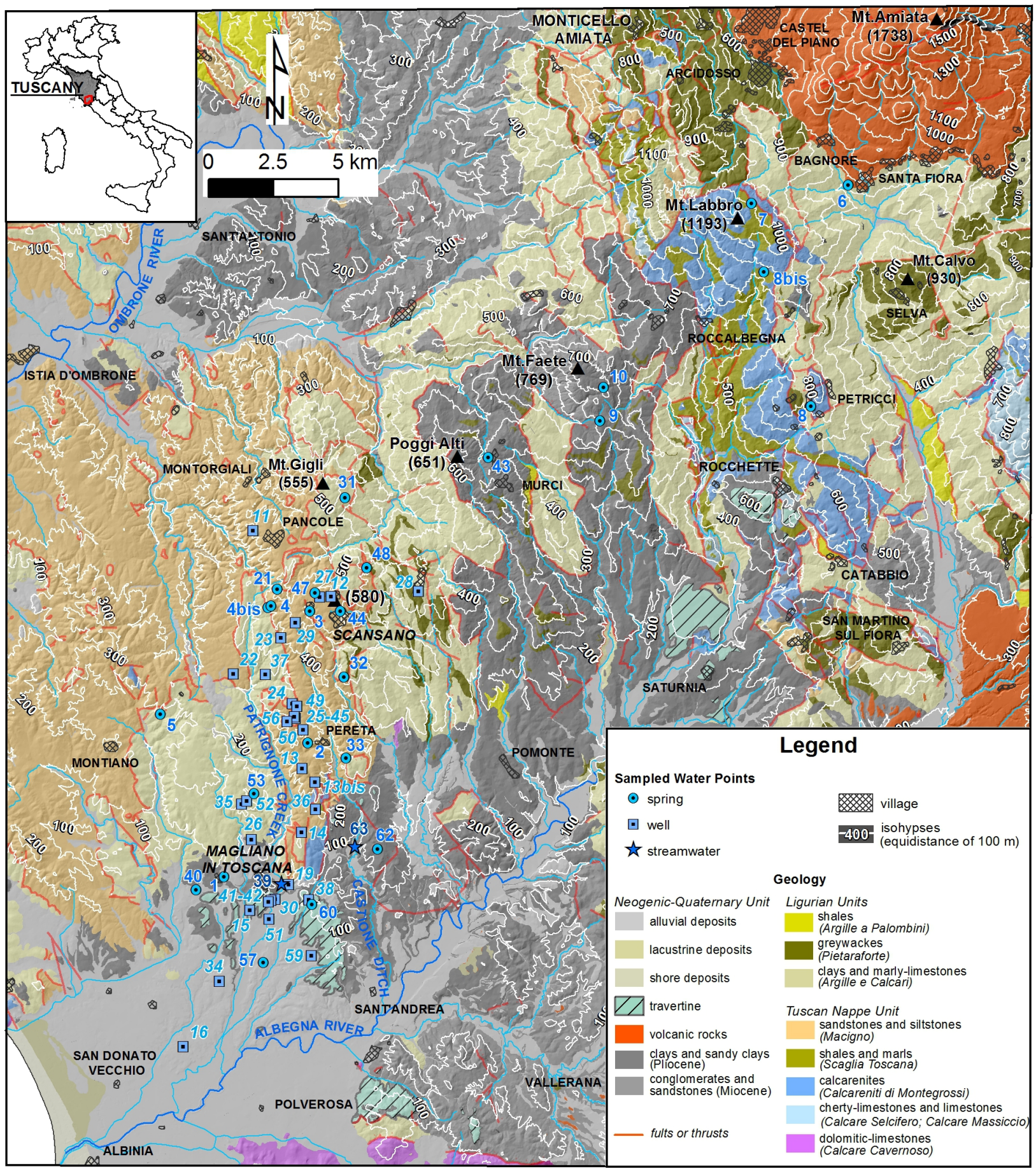

\section{Study Area and Methods}

\subsection{Climate, Geology and Hydrogeology}

The Scansano-Magliano in Toscana ridge is located in southern Tuscany between the Albegna and Ombrone rivers (Figure 1). It develops S-N between 50 and $580 \mathrm{~m}$ (a.s.1.) of altitude, starting from the Albegna plain. The main streamwaters in the studied area are the Patrignone creek and the Castione 
ditch, which develop from Scansano toward Magliano in Toscana area, where they flow into the Albegna River.

Using the data collected by Tuscan Region Administration at the "Scansano raingauge" and "Manciano thermometric" stations [10], the average annual values of rainfall and temperature of the area can be assessed as about $880 \mathrm{~mm}$ and $14.5{ }^{\circ} \mathrm{C}$, respectively. Based on sixty years of hydrology data, the maximum value of rainfall is in November (about $125 \mathrm{~mm}$ ), whereas the minimum is in July (about $25 \mathrm{~mm}$ ); the thirteen years of temperature data that are available highlight that the minimum and maximum values of average temperature occur in January (about $6{ }^{\circ} \mathrm{C}$ ) and August (about $23{ }^{\circ} \mathrm{C}$ ). According to Vittorini (1972) [11] the area belongs to subhumid and subarid climate classes.

From a geological point of view, the study area fits into an inner portion of the northern Apennine chain, which is characterized by eastward nappe stacking. In particular, the tectonic evolution is characterized by early compressional stages, started in the Early-Cretaceous, with the progressive suture of the Jurassic Ligurian ocean by convergence of Adria and European plates, leading to continental collision in the Middle Eocene ([12-15] and references therein). The convergence continued during the post-Oligocene with the eastward overthrusting of the Ligurian Units (derived from the oceanic domain and its transition to the continental margin) on the detached sedimentary cover of the continental margin (Tuscan Nappe) [16-18]. From the Middle Miocene, the structural stacking was affected by extensional processes, related to the development of the Tyrrhenian Sea [19-21]. Such processes generated Plio-Pleistocene basins, interpreted by many authors as controlled by longitudinal systems of high angle normal faults, assuming a continuous extensional regime from the Middle Miocene to the Present [21-23]. The tectonic depressions of the Neogene Basins have been so affected by a deposition of continental and marine sediments (Neogene-Quaternary age). Moreover, the extensional regime also controlled the emplacement of magmatic bodies at limited depths and in some case the eruption of volcanic products (e.g., the Mt. Amiata volcanic rocks; Figure 1).

In this geological framework, the Scansano-Magliano in Toscana zone and its surrounding areas are characterized by three main units (Figure 1): (1) the youngest one (Neogene-Quaternary age) mainly consists of alluvial deposits, travertines, volcanic rocks, Pliocenic clays and sandy clays, and Miocenic conglomerates and sandstones; (2) the Tuscan Nappe Unit, here represented by sandstones and siltstones (Macigno formation, upper Oligocene-lower Miocene), shales and marls (Scaglia Toscana formation), calcarenites (Calcareniti di Montegrossi formation), cherty-limestones and limestones (formations of Calcare Selcifero, Calcare Massiccio), and dolomitic-limestones (Calcare Cavernoso); (3) the Ligurian Units, consisting of greywackes (Pietraforte Formation, Medium-Upper Cretaceous), shales (Argille a Palombini formation) and of a sequence of clays and marly-limestones (mainly Argille e Calcari formation).

Based on this geological context, some major hydrogeological units can be defined:

- The first unit consists of alluvial deposits, travertine and Miocenic sand, and it is characterized by medium to high permeability;

- The second unit is composed by volcanic rocks, whose permeability is medium-high to high;

- The third unit, composed of Pliocene clays, is considered impermeable; 
- The fourth unit consists of siltstones, shales and of a sequence of clays and marly-limestones (mainly Ligurian Units and Scaglia Toscana formation), and has medium-low to very low permeability;

- The fifth unit is represented by sandstones (mainly Macigno formation and to a lesser extent Pietraforte formation). This unit is considered to have medium to medium-low permeability.

- The sixth unit, made up by calcarenites, cherty-limestones, limestones and dolomitic-limestones of the Tuscan Nappe. Its permeability is medium to very high.

In the specific zone of the Scansano-Magliano in Toscana ridge, the most important hydrogeological complex is represented by the sandstones of the Macigno formation, because it covers with continuity a surface of about $35 \mathrm{~km}^{2}$ and it is limited, both downward and laterally (eastward and westward), by medium-low to very low permeability complexes mainly made up by shales and marly-limestones ("Scaglia Toscana" and "Argille e Calcari" of the Tuscan Nappe and Ligurian Unit, respectively). Because the sandstone outcrops and is unconfined in this area, a significant groundwater body can be presumed to reside within this complex, also taking into account the brittle deformation that may have locally improved the general medium degree of permeability. Indeed, Francese et al. (2009) [24] highlighted a complex geometry of the fracture network in the Scansano area, which presents fractures and faults with major NNW-SSE, N-S and E-W trends. Several farm wells already exploit this resource, which is also drained by some springs with average flowrate of the order of $0.5 \mathrm{~L} / \mathrm{s}$. Only a few springs and wells are present on the marly-limestones outcropping westward and eastward, showing only minor groundwater flow there.

\subsection{Methodology}

During the 2004-2005 period, six sampling fields were carried out in order to collect water sample from 25 springs, 31 wells and 2 stream waters (120 samples in total). Analyses were performed to achieve the abundance ratios of the water stable isotopes $\left({ }^{18} \mathrm{O} /{ }^{16} \mathrm{O},{ }^{2} \mathrm{H} /{ }^{1} \mathrm{H}\right)$, which are expressed as $\delta \%$ compared to the V-SMOW standard [25], and the ${ }^{3} \mathrm{H}$ content (expressed as tritium units, TU; $1 \mathrm{TU}=1{ }^{3} \mathrm{H}$ atom every $10^{18}$ total hydrogen atoms). The $\delta^{18} \mathrm{O} \%$ was analyzed for each collected sample, whereas $\delta^{2} \mathrm{H} \%$ values and tritium contents were achieved for 90 and 40 samples, respectively.

The $\delta^{18} \mathrm{O}$ value was determined through analysis of gaseous $\mathrm{CO}_{2}$, previously equilibrated with water at $25{ }^{\circ} \mathrm{C}$ [26]. The mass-spectrometric measurement of the ${ }^{18} \mathrm{O} /{ }^{16} \mathrm{O}$ ratio requires correction, because a fractionation between $\mathrm{CO}_{2}$ and $\mathrm{H}_{2} \mathrm{O}$ occurs. Analytical precision on $\delta^{18} \mathrm{O} \%$ values is better than $0.10 \%$. The $\delta^{2} \mathrm{H}$ value was measured by reducing the water to elemental hydrogen [27] using magnesium instead of zinc. Because the totality of water is reduced and all hydrogen is converted to hydrogen gas, the isotopic fractionation does not occur and a correction of the mass-spectrometric measurement is not necessary. The analytical error for $\delta^{2} \mathrm{H}$ is $1.5 \%$. The isotopic ratios of $\mathrm{CO}_{2}$ and $\mathrm{H}_{2}$ were measured by dual inlet mass spectrometer.

Tritium is a short-lived isotope of hydrogen with a half-life of 12.3 years. It is analyzed through measurement of $\beta^{-}$decay events in a liquid scintillation counter. Direct liquid-scintillation counting has a precision of $7 \mathrm{TU}$. For tritium contents lower than $20 \mathrm{TU}$, increased precision is gained through concentration by electrolytic enrichment of ${ }^{3} \mathrm{H}$ in the water before counting, thus reaching a precision better than $0.8 \mathrm{TU}$. 
As shown in Figure 1, the sampled water points are distributed not only along the Scansano-Magliano in Toscana ridge but also in its surrounding areas. Such points were selected with the aim to define, in terms of groundwater flow, the relationships between the sandstone aquifer and the other hydrogeological complexes, and moreover to obtain a good isotopic characterization of the rainfall/infiltration water. Indeed, the application of isotopic methods is closely dependent on the knowledge of some local parameters, such as the distribution of the isotopic composition of rainwater/infiltration water and vertical isotopic gradient in the area. This basic information is obtained by examining the $\delta^{18} \mathrm{O} \%$, $\delta^{2} \mathrm{H} \%$ and ${ }^{3} \mathrm{H}$ in the rainwater collected every month and at various altitudes for a period of at least two-three years (e.g., [28]). In the absence of a well distributed raingauge-network, but also to avoid the long time required by this methodology and to get information directly on the infiltrated water, it is possible to collect some samples (3-4 each year) in small springs (low flowrate) that are fed by limited extension basins (e.g., $[8,29]$ ). In this way the stable isotopes of the water are representative of an infiltration average altitudes that is not very different from the springs' altitudes and assessable by morphological and hydrogeological considerations. In order to minimize the error in the assessing of the infiltration average altitudes, it is preferable to identify springs at the base of small reliefs and in hydrostructural contexts that suggest a local circulation of groundwater (see the example in Figure 2).

Figure 2. Cross section (A-B) in the zone of the spring " 8 ".

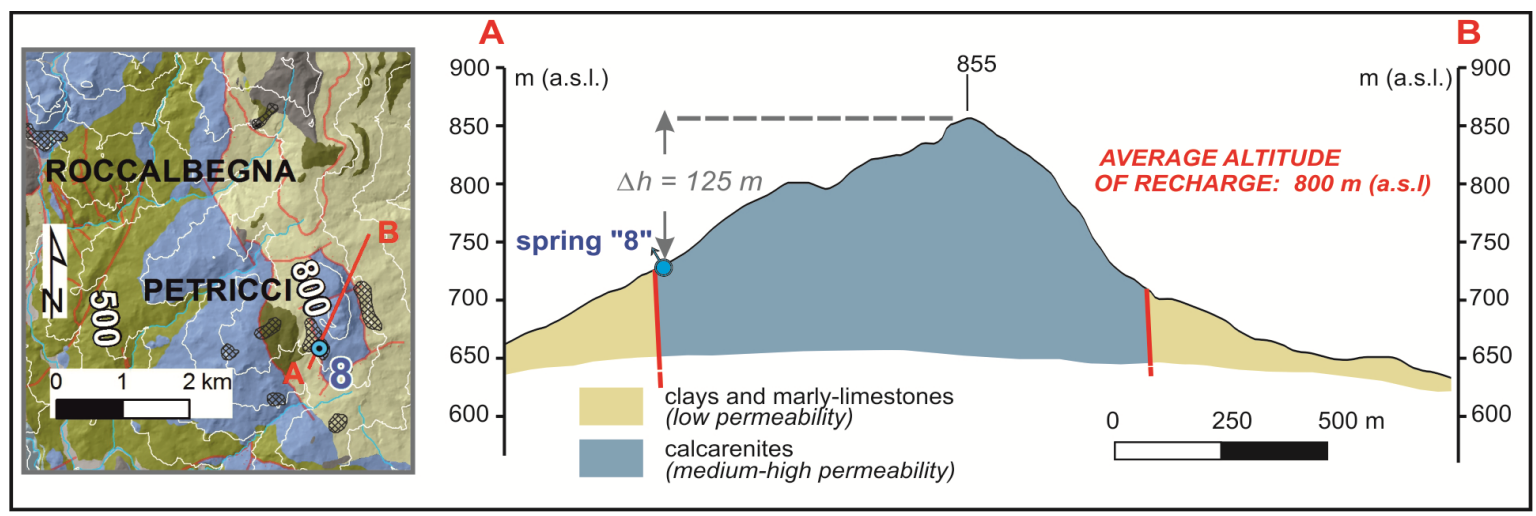

Based on the latter approach, several springs with low flowrate were identified over the altitude interval of 40-995 $\mathrm{m}$ a.s.1. These springs are representative of a groundwater circulation in aquitard complexes, or in aquifers complexes that have a limited extension. Despite its high flowrate and wide recharge area, the main spring draining the Mt. Amiata volcanic aquifer [30] was also included, in order to achieve isotopic information that are representative of the highest altitudes encountered in the area surrounding the site under examination. The data derived from all these selected springs allowed fundamental background information to be obtained, e.g., the relationship altitude $/ \delta^{18} \mathrm{O} \%$ (or alternatively altitude $/ \delta^{2} \mathrm{H} \%$ ), which was then used to assess the average altitude of the feeding area for the groundwater tapped by wells into the hydrogeological complexes of the Scansano-Magliano in Toscana area.

The tritium values achieved for the water points were also compared with the tritium annual data of rainfall, which were recorded at the Genova and Pisa stations [29,31,32]. This data can be considered homogeneous in the whole Mediterranean area and not affected by the precipitation altitudes [29]. In order to conduct a preliminary assessment of the average residence time of groundwater flow, the 
exponential law of radioactive decay was applied to the ${ }^{3} \mathrm{H}$ average annual values of rainfall occurred in the past years, and the achieved results were compared with the contents of water points under examination.

\section{Results and Discussion}

\subsection{Isotopic Features of the Infiltration Water}

In order to define isotopic features of infiltration water, samples collected at 25 springs, which are located in the area between Magliano in Toscana and the Mt. Amiata (Figure 1), were analyzed. Seventeen of such springs were sampled at least two time in different periods, whereas the remaining springs were collected only once.

The selection of the springs was performed on the base of morphological and hydrostructural conditions, with the aim to individuate water points which represent local groundwater, whose average altitudes of feeding are similar to the springs' altitudes and assessable with a good approximation (see Figure 2, such as example among the several elaborated hydrogeological sections). In this way, the relationship between infiltration average altitudes and isotopic values (in particular that of stable isotopes) can be achieved. The only exception is spring 6, which has an extended recharge area, whose average altitude was estimated on the base of previous studies [30,33].

Results of isotopic analyses are reported in Table 1. For the springs that were analyzed more than once, the isotopic composition was observed to be stable over time. Given this general behavior, in the data processing and interpretation the average isotopic values were considered for such springs; moreover, also for the springs that were sampled only once, the isotopic values were involved as representative of the annual average values.

The $\delta^{2} \mathrm{H} \%$ and $\delta^{18} \mathrm{O} \%$ values of the springs are compared in Figure 3 with the global meteoric (GMWL) [34] and the Mediterranean meteoric (MMWL) [35] water lines. The spring water fall between these two lines and give a regression line equation of $\delta^{2} \mathrm{H} \%=5.7 \times \delta^{18} \mathrm{O} \%{ }_{0}-2.4\left(\mathrm{R}^{2}=0.97\right)$, which can be considered as representative of the local meteoric water line (LMWL). As previously observed in the southern Tuscany (e.g., [36]), groundwater points dispose between the GMWL and the MMWL with a slope lesser than 8. Taking also into account that the low and high altitude springs fall close to GMWL and MMWL, respectively, such behavior likely reflects an evaporative influence on the isotopic values of rainfall of Mediterranean origin. The wide range of values observed for $\delta^{18} \mathrm{O}$ and $\delta^{2} \mathrm{H}$ (about $2.5 \%$ and $15 \%$, respectively) is nevertheless mainly linked to the altitude effect. 
Table 1. Springs isotopic data.

\begin{tabular}{|c|c|c|c|c|c|c|c|c|}
\hline $\begin{array}{l}\text { Sampled } \\
\text { Springs }\end{array}$ & $\begin{array}{c}\text { Spring } \\
\text { Altitudes } \\
\text { (m a.s.l.) }\end{array}$ & $\begin{array}{l}\text { Infiltration } \\
\text { Average } \\
\text { Altitudes * } \\
\text { (m a.s.l.) } \\
\end{array}$ & $\begin{array}{c}\delta^{18} \mathrm{O} \% \text { (VSMOW) } \\
\text { (Precision 0.10\%) } \\
\text { Mean Value or } \\
\text { Single Datum } \\
\end{array}$ & $\begin{array}{c}\delta^{18} \text { O\%o Values } \\
\text { (March 04/June-July 04/ } \\
\text { September 04/May-June 05/ } \\
\text { September 05/October 05) }\end{array}$ & $\begin{array}{c}\delta^{2} \mathrm{H} \% \text { (VSMOW) } \\
\text { (Precision 1.5\%) } \\
\text { Mean Value or } \\
\text { Single Datum } \\
\end{array}$ & $\begin{array}{c}\delta^{2} \text { H\%o Values } \\
\text { (March 04/June-July 04/ } \\
\text { September 04/May-June 05/ } \\
\text { September 05/October 05) }\end{array}$ & $\begin{array}{c}{ }^{3} \mathrm{H}(\mathrm{TU}) \pm \text { Err } \\
\text { Mean Value or } \\
\text { Single Datum }\end{array}$ & $\begin{array}{c}{ }^{3} \text { H(TU) Values } \\
\text { (March 04/June-July 04/ } \\
\text { September 04/May-June 05/ } \\
\text { September 05/October 05) }\end{array}$ \\
\hline 1 & 75 & 150 & -5.58 & $(-5.53 /-5.54 /-5.63 / \mathrm{ns} /-5.62 / \mathrm{ns})$ & -34.2 & $(-33.6 /-33.2 /-35.8 / \mathrm{ns} / \mathrm{na} / \mathrm{ns})$ & $2.9 \pm 0.7$ & (na/3.0/2.8/ns/na/ns) \\
\hline 2 & 260 & 310 & -6.24 & $(-6.28 /-6.18 / \mathrm{ns} /-6.25 / \mathrm{ns} / \mathrm{ns})$ & -38.5 & $(-38.1 /-38.9 / \mathrm{ns} / \mathrm{na} / \mathrm{ns} / \mathrm{ns})$ & $4.7 \pm 0.7$ & (na/4.7/ns/na/ns/ns) \\
\hline 3 & 490 & 530 & -6.68 & $(-6.59 /-6.71 /-6.73 /-6.67 / \mathrm{ns} / \mathrm{ns})$ & -39.4 & $(-38.3 /-40.4 /-39.4 / \mathrm{na} / \mathrm{ns} / \mathrm{ns})$ & na & (na/na/ns/na/ns/ns) \\
\hline 4 & 380 & 500 & -6.64 & $(-6.62 /-6.65 / \mathrm{ns} / \mathrm{ns} / \mathrm{ns} / \mathrm{ns})$ & -40.3 & $(-39.4 /-41.2 / \mathrm{ns} / \mathrm{ns} / \mathrm{ns} / \mathrm{ns})$ & na & (na/na/ns/ns/ns/ns) \\
\hline 4bis & 395 & 500 & -6.74 & $(-6.79 /-6.68 / \mathrm{ns} / \mathrm{ns} / \mathrm{ns} / \mathrm{ns})$ & -40.2 & $(-38.6 /-41.7 / \mathrm{ns} / \mathrm{ns} / \mathrm{ns} / \mathrm{ns})$ & na & (na/na/ns/ns/ns/ns) \\
\hline 5 & 175 & 200 & -5.57 & $(-5.54 /-5.56 /-5.55 /-5.61 / \mathrm{ns} / \mathrm{ns})$ & -34.1 & $(-34.4 /-34.6 /-32.3 / \mathrm{na} / \mathrm{ns} / \mathrm{ns})$ & $4.2 \pm 0.6$ & (na/na/4.2/na/ns/ns) \\
\hline 6 & 650 & 1300 & -7.89 & $(-8.00 /-7.83 /-7.86 /-7.86 / \mathrm{ns} / \mathrm{ns})$ & -48.3 & $(-47.9 /-47.4 /-49.5 / \mathrm{na} / \mathrm{ns} / \mathrm{ns})$ & $6.3 \pm 0.7$ & (na/na/6.3/na/ns/ns) \\
\hline 7 & 995 & 1080 & -7.42 & $(-7.52 /-7.30 /-7.33 /-7.51 / \mathrm{ns} / \mathrm{ns})$ & -44.8 & $(-44.8 /-43.6 /-45.9 / \mathrm{na} / \mathrm{ns} / \mathrm{ns})$ & $5.5 \pm 0.7$ & (na/na/5.5/na/ns/ns) \\
\hline 8 & 730 & 800 & -6.97 & $(-7.03 /-6.94 /-6.96 /-6.93 /-6.99 / \mathrm{ns})$ & -41.9 & $(-40.4 /-43.0 /-42.3 / \mathrm{na} / \mathrm{na} / \mathrm{ns})$ & $5.5 \pm 0.8$ & (na/na/5.5/na/na/ns) \\
\hline 8bis & 845 & 950 & -7.17 & $(-7.29 /-7.17 /-7.06 / \mathrm{ns} / \mathrm{ns} / \mathrm{ns})$ & -44.2 & $(-44.1 /-44.5 /-43.9 / \mathrm{ns} / \mathrm{ns} / \mathrm{ns})$ & na & (na/na/na/ns/ns/ns) \\
\hline 9 & 630 & 660 & -6.66 & $(-6.67 /-6.64 / \mathrm{ns} / \mathrm{ns} / \mathrm{ns} / \mathrm{ns})$ & -40.7 & $(-39.6 /-41.7 / \mathrm{ns} / \mathrm{ns} / \mathrm{ns} / \mathrm{ns})$ & $4.7 \pm 0.7$ & (na/4.7/ns/ns/ns/ns) \\
\hline 10 & 690 & 730 & -6.81 & $(-6.86 /-6.79 /-6.73 /-6.85 / \mathrm{ns} / \mathrm{ns})$ & -41.4 & $(-40.7 /-41.5 /-41.9 / \mathrm{na} / \mathrm{ns} / \mathrm{ns})$ & $4.1 \pm 0.6$ & (na/4.2/4.0/na/ns/ns) \\
\hline 21 & 460 & 510 & -6.69 & $(\mathrm{~ns} /-6.69 / \mathrm{ns} / \mathrm{ns} / \mathrm{ns} / \mathrm{ns})$ & -39.7 & $(\mathrm{~ns} /-39.7 / \mathrm{ns} / \mathrm{ns} / \mathrm{ns} / \mathrm{ns})$ & na & (ns/na/ns/ns/ns/ns) \\
\hline 31 & 450 & 540 & -6.53 & $(\mathrm{~ns} / \mathrm{ns} /-6.50 /-6.56 / \mathrm{ns} / \mathrm{ns})$ & -41.0 & $(\mathrm{~ns} / \mathrm{ns} /-41.0 / \mathrm{na} / \mathrm{ns} / \mathrm{ns})$ & $4.8 \pm 0.8$ & (ns/ns/4.8/na/ns/ns) \\
\hline 32 & 400 & 430 & -6.28 & $(\mathrm{~ns} / \mathrm{ns} /-6.27 /-6.24 /-6.32 / \mathrm{ns})$ & -38.6 & (ns/ns/-38.6/na/na/ns) & na & (ns/ns/na/na/na/ns) \\
\hline 33 & 180 & 250 & -6.03 & $(\mathrm{~ns} / \mathrm{ns} /-5.98 /-6.08 / \mathrm{ns} / \mathrm{ns})$ & -36.6 & (ns/ns/-36.6/na/ns/ns) & na & (ns/ns/na/na/ns/ns) \\
\hline 40 & 45 & 150 & -5.65 & $(\mathrm{~ns} / \mathrm{ns} / \mathrm{ns} /-5.65 / \mathrm{ns} / \mathrm{ns})$ & -33.2 & $(\mathrm{~ns} / \mathrm{ns} / \mathrm{ns} /-33.2 / \mathrm{ns} / \mathrm{ns})$ & na & $(\mathrm{ns} / \mathrm{ns} / \mathrm{ns} / \mathrm{na} / \mathrm{ns} / \mathrm{ns})$ \\
\hline 43 & 545 & 630 & -6.74 & $(\mathrm{~ns} / \mathrm{ns} / \mathrm{ns} /-6.74 / \mathrm{ns} / \mathrm{ns})$ & -40.5 & $(\mathrm{~ns} / \mathrm{ns} / \mathrm{ns} /-40.5 / \mathrm{ns} / \mathrm{ns})$ & na & $(\mathrm{ns} / \mathrm{ns} / \mathrm{ns} / \mathrm{na} / \mathrm{ns} / \mathrm{ns})$ \\
\hline 44 & 490 & 520 & -6.62 & $(\mathrm{~ns} / \mathrm{ns} / \mathrm{ns} /-6.73 / \mathrm{ns} /-6.40)$ & -39.6 & (ns/ns/ns/-39.6/ns/na) & $3.4 \pm 0.6$ & $(\mathrm{~ns} / \mathrm{ns} / \mathrm{ns} / 3.4 / \mathrm{ns} / \mathrm{na})$ \\
\hline 47 & 515 & 530 & -6.60 & $(\mathrm{~ns} / \mathrm{ns} / \mathrm{ns} / \mathrm{ns} /-6.60 /-6.60)$ & -39.6 & (ns/ns/ns/ns/-39.6/na) & $5.9 \pm 0.6$ & (ns/ns/ns/ns/5.9/na) \\
\hline 48 & 490 & 530 & -6.43 & $(\mathrm{~ns} / \mathrm{ns} / \mathrm{ns} / \mathrm{ns} /-6.46 /-6.40)$ & -39.4 & (ns/ns/ns/ns/-39.4/na) & $5.8 \pm 0.6$ & (ns/ns/ns/ns/5.8/na) \\
\hline 53 & 190 & 240 & -5.95 & $(\mathrm{~ns} / \mathrm{ns} / \mathrm{ns} / \mathrm{ns} /-5.95 / \mathrm{ns})$ & -37.5 & $(\mathrm{~ns} / \mathrm{ns} / \mathrm{ns} / \mathrm{ns} /-37.5 / \mathrm{ns})$ & na & (ns/ns/ns/ns/na/ns) \\
\hline 57 & 40 & 50 & -5.55 & $(\mathrm{~ns} / \mathrm{ns} / \mathrm{ns} / \mathrm{ns} / \mathrm{ns} /-5.55)$ & -34.3 & $(\mathrm{~ns} / \mathrm{ns} / \mathrm{ns} / \mathrm{ns} / \mathrm{ns} /-34.3)$ & na & (ns/ns/ns/ns/ns/na) \\
\hline 60 & 95 & 130 & -5.62 & $(\mathrm{~ns} / \mathrm{ns} / \mathrm{ns} / \mathrm{ns} / \mathrm{ns} /-5.62)$ & -34.8 & $(\mathrm{~ns} / \mathrm{ns} / \mathrm{ns} / \mathrm{ns} / \mathrm{ns} /-34.8)$ & $4.3 \pm 0.5$ & $(\mathrm{~ns} / \mathrm{ns} / \mathrm{ns} / \mathrm{ns} / \mathrm{ns} / 4.3)$ \\
\hline 62 & 140 & 170 & -5.85 & $(\mathrm{~ns} / \mathrm{ns} / \mathrm{ns} / \mathrm{ns} / \mathrm{ns} /-5.85)$ & -36.8 & $(\mathrm{~ns} / \mathrm{ns} / \mathrm{ns} / \mathrm{ns} / \mathrm{ns} /-36.8)$ & na & (ns/ns/ns/ns/ns/na) \\
\hline
\end{tabular}

Notes: *: assessed by morphological and hydrogeological considerations. The only exception is for the spring 6 (see text); ns: not sampled; na: not analyzed. 
Figure 3. $\delta^{2} \mathrm{H} \%$ ovs. $\delta^{18} \mathrm{O} \%$ for the spring samples.

$\delta^{180}$ (\% vs VSMOW)

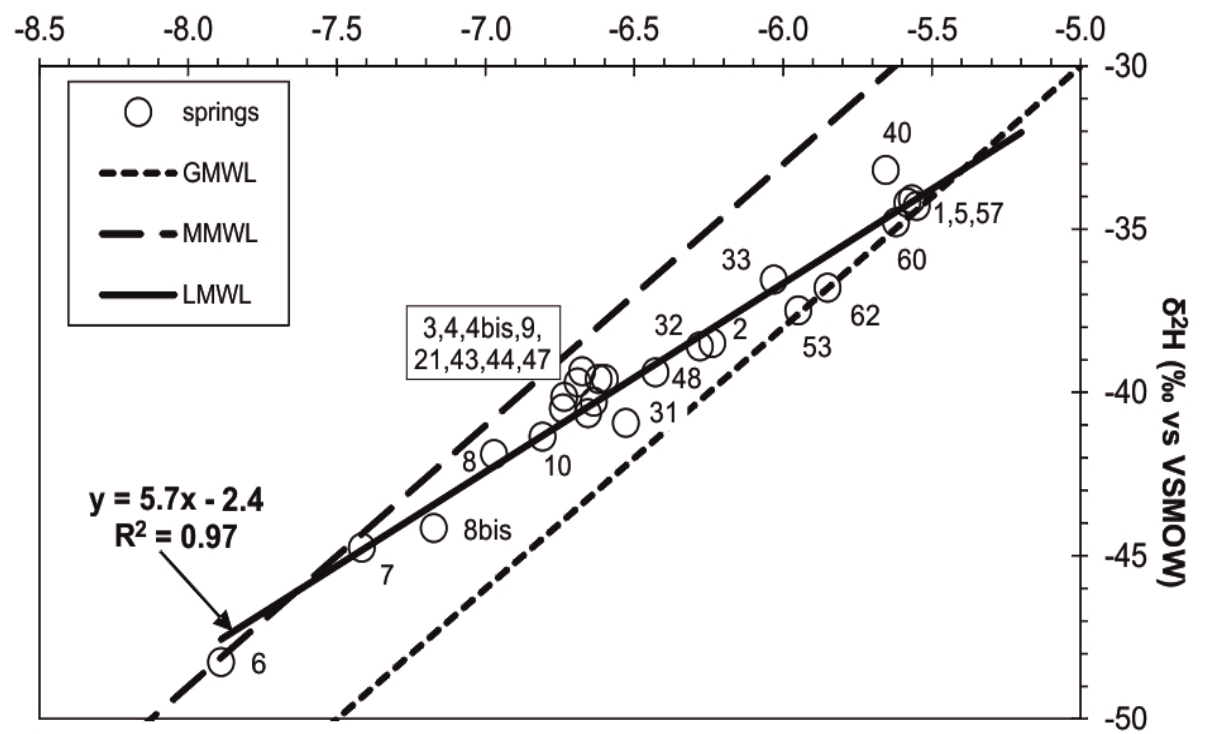

The regression line showing the $\delta^{18} \mathrm{O} \%$ values variation with the altitude is achieved in Figure 4 by means of a comparison among the isotopic contents of the springs and the respective estimated basin average altitudes. The springs 3, 4, 4bis, 21, 44, 47 (located nearby Scansano; Figure 1) and 2 (sited nearby Pereta; Figure 1) are not involved in the computed regression line, because, if compared to the behavior of the other springs, they show an incompatibility between the estimated feeding average altitudes and the respective $\delta^{18} \mathrm{O} \%$ values. In other words, the isotopic contents of these springs require higher recharge altitudes in respect to the estimated ones. On the other hand such required altitudes are not detectable on the hilly reliefs neighboring the springs, so the latter seem to drain not only local groundwater but also more extended flow paths, which will be discussed in the next paragraph.

Figure 4. Recharge average altitudes $v s . \delta^{18} \mathrm{O} \%$ o for the spring waters (see text for the methodology through which the recharge altitudes were estimated).

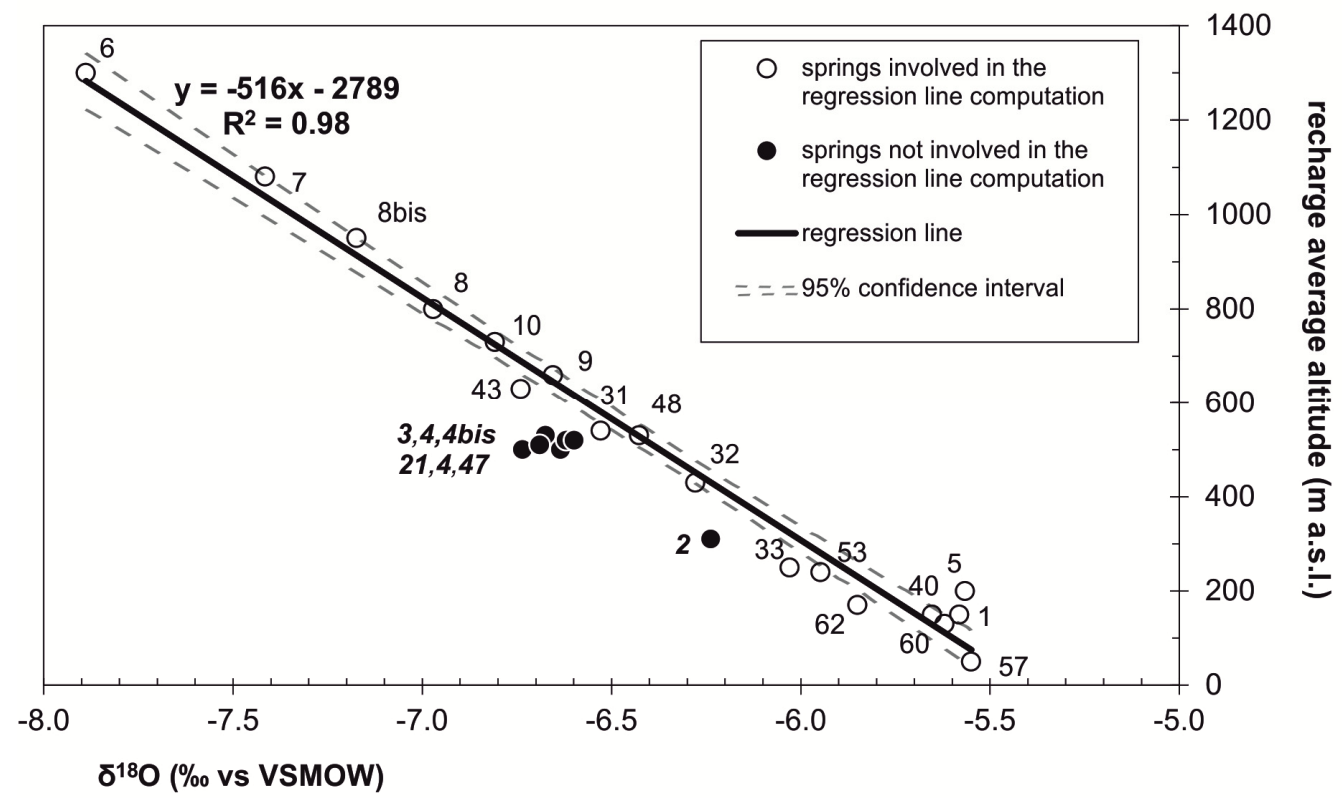


The regression line equation is "Altitude $(\mathrm{m})=-516 \times \delta^{18} \mathrm{O} \% \mathrm{-}-2789$ " $\left(\mathrm{R}^{2}=0.98\right)$ and will be used to assess the feeding average altitude of the major groundwater flow systems. The $\delta^{18} \mathrm{O}$ vertical gradient is about $-0.2 \%$ every 100 meters of altitude increasing, with a $\delta^{18} \mathrm{O} \%$ of about -5.4 at sea level. Such values are in agreement with those generally observed along the Tyrrhenian coast of Italy [28,29,37-39].

Fourteen of the 25 sampled springs were analyzed for tritium contents, achieving values between 2.9 and $6.3 \mathrm{TU}$ (Table 1). In order to achieve preliminary indications on the average age of the spring water, such contents were compared to the rainfall tritium values, the latter opportunely depleted according to the decay low (Figure 5). Most of the analyzed springs showed tritium values between 3.4 and 5.5 TU, which are likely linked to the rainfall annual values of the recent years, taking also into account that such springs drain local flow path from unconfined systems. The $6.3 \mathrm{TU}$ of the spring 6 indicate an average residence time of about 20 years or longer, in agreement with the extension and hydrodynamic behavior of the volcanic aquifer which is drained by the same spring [30,33]. In addition, the values of 5.9 and $5.8 \mathrm{TU}$, which were detected for the springs 47 and 48 , can be representative of an average age of 20 or more years, anyway such springs were analyzed only once and the relative values may be affected by annual fluctuations that occur in rainfall tritium contents. Finally, groundwater drained by the spring 1, which showed 2.9 TU practically constant in two samplings performed at different periods of the same year, seems to have an average residence time longer than 20 years, which is congruent with the marly lithology in which the relative aquifer is developed.

Figure 5. Tritium values of the springs in comparison to tritium values of precipitations.

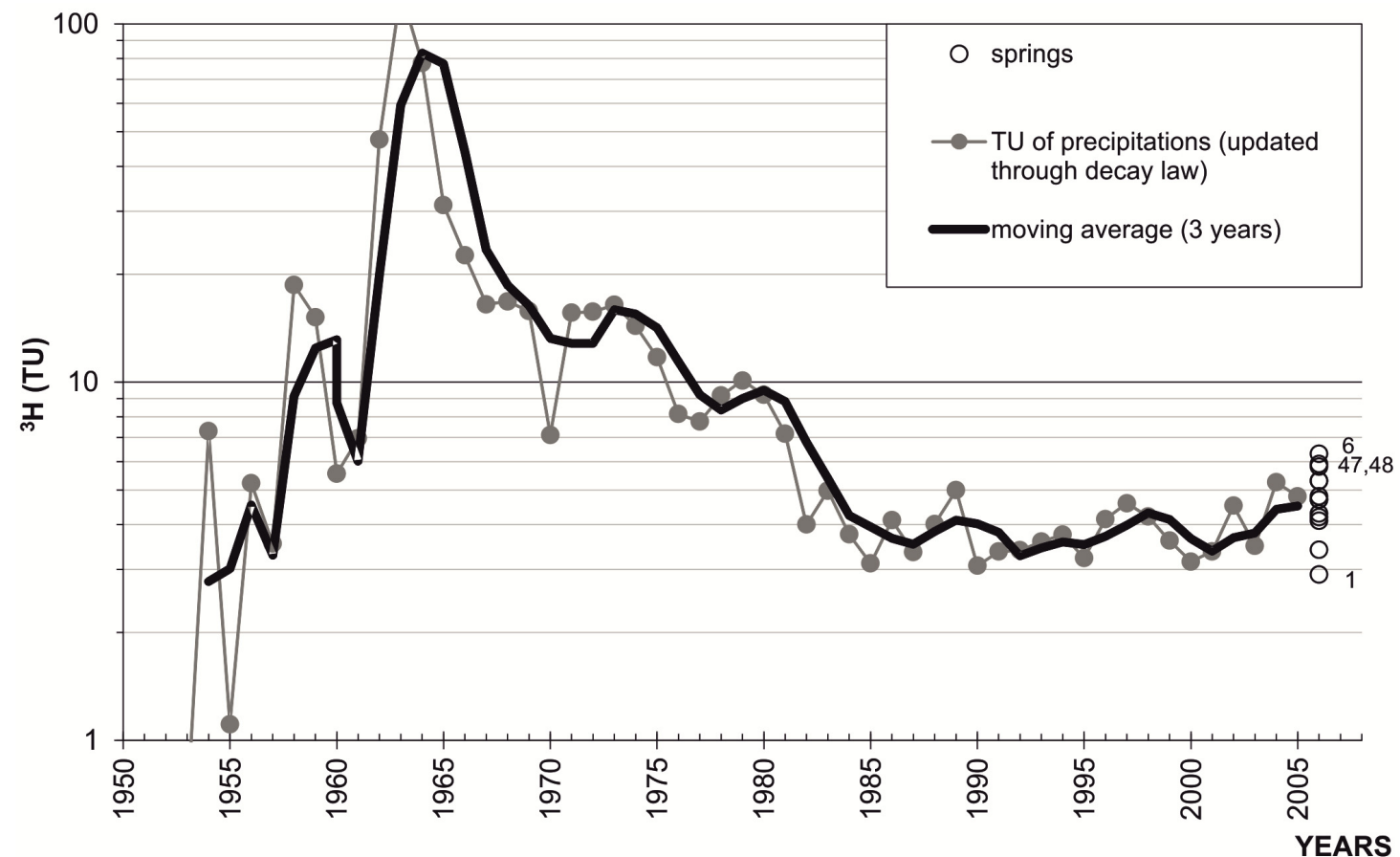

\subsection{Groundwater Flow Framework}

The isotopic data of the water collected at the wells and streamwaters located in the Scansano-Magliano in Toscana area are inserted in Table 2. Water from wells generally showed an 
isotopic stability over time, which indicates groundwater flow in the region is not significantly affected by the seasonal isotopic variability of the rainfall. Thus, the average isotopic values can be used for the discussion of the source of groundwater flow. As showed by Figure 6, the wells waters cluster along the local meteoric line (LMWL). Consequently, isotopic exchange phenomena does not appear to be an issue for the groundwater at this study site and the observed features are completely linkable at that of the infiltration water, or, in other words, water stable isotopes work as environmental tracers.

The range of $\delta^{18} \mathrm{O}$ in the well water was from $-6.75 \%$ to $-5.35 \%$, with the lighter signatures referred at the Scansano-Pancole zone and the heavier ones registered in the Albegna Plain. A general increasing of the values is observed moving from Scansano to Magliano in Toscana, with a substantial agreement with a decrease in altitude. However, this trend and the distribution of the absolute values across the territory seem to be also affected by the hydro-structural features. Generally, the lighter signatures were detected for most of the wells that tap into the sandstones aquifer (Figures 6 and 7), whereas the heavier $\delta^{18} \mathrm{O}$ signatures were found in the groundwater flowing into the marly/shaly complexes. These features for groundwater flow hosted in the sandstones is confirmed by the isotopic values of the springs that drain this aquifer in the Scansano zone. Two groundwater flow systems can be so identified in the Scansano-Magliano in Toscana ridge: (i) the first concerns the marly/shaly complexes and have heavier isotopic signatures; (ii) the second develops in the sandstones aquifer and shows lighter isotopic signatures.

Figure 6. $\delta^{2} \mathrm{H} \%$ v vs. $\delta^{18} \mathrm{O} \%$ o for the wells waters. (1) wells into the sandstones; (2) wells into the other hydrogeological complexes; LMWL is as defined in Figure 3.

\section{$\delta^{18} \mathrm{O}(\%$ vs VSMOW)}

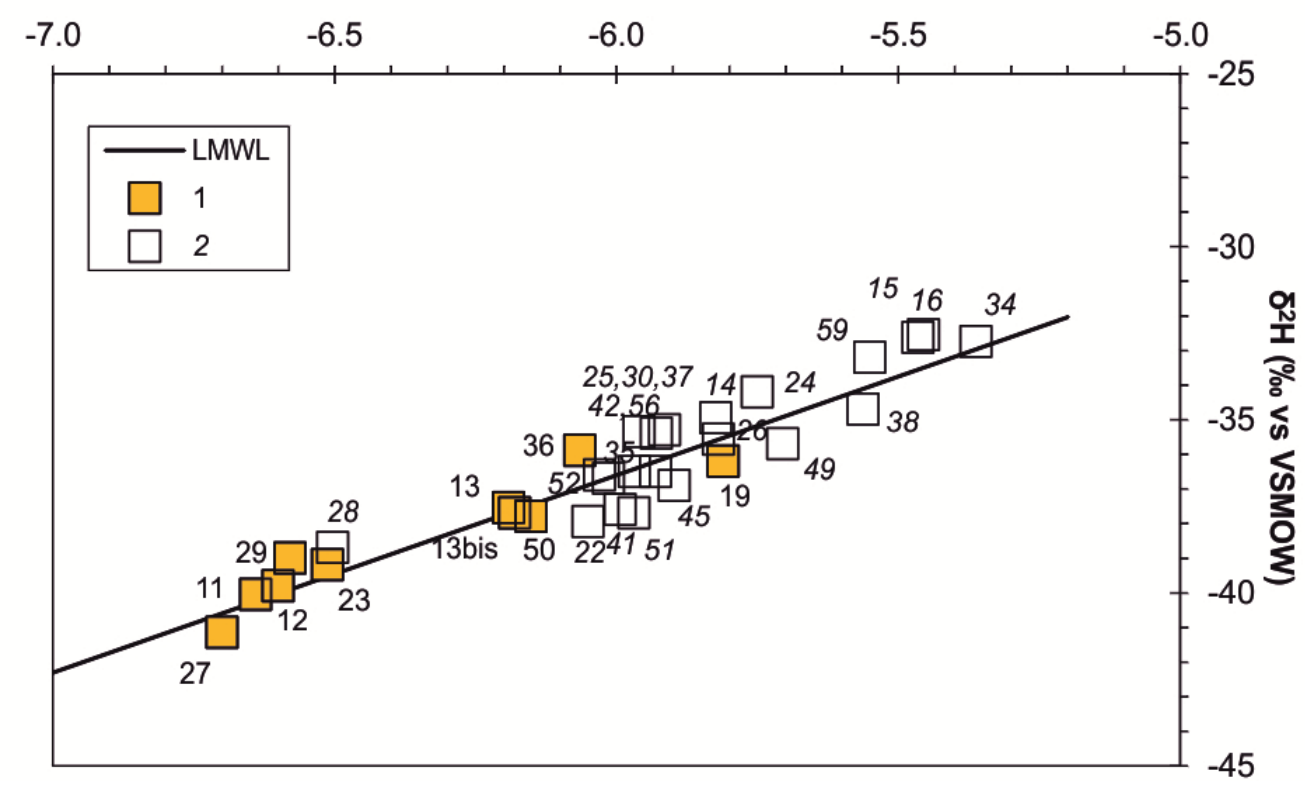


Table 2. Isotopic data of wells and streamwaters.

\begin{tabular}{|c|c|c|c|c|c|c|c|c|}
\hline $\begin{array}{l}\text { Sampled Wells } \\
\text { or } \\
\text { Streamwaters }\end{array}$ & $\begin{array}{c}\text { Altitudes of } \\
\text { Ground Level } \\
\text { (m a.s.l.) }\end{array}$ & $\begin{array}{l}\text { Depth of Well } \\
\text { (m) or } \\
\text { Name of } \\
\text { Streamwater }\end{array}$ & $\begin{array}{c}\delta^{18} \text { O\%o(VSMOW) } \\
\text { (Precision 0.10\%) } \\
\text { Mean Value or } \\
\text { Single Datum } \\
\end{array}$ & $\begin{array}{c}\delta^{18} \text { O\%o Values } \\
\text { (March 04/June-July 04/ } \\
\text { September 04/May-June 05/ } \\
\text { September 05/October 05) }\end{array}$ & $\begin{array}{c}\delta^{2} H \%(\text { VSMOW) } \\
\text { (Precision 1.5\%) } \\
\text { Mean Value or } \\
\text { Single Datum } \\
\end{array}$ & $\begin{array}{c}\delta^{2} \mathrm{H} \% \text { Values } \\
\text { (March 04/June-July 04/ } \\
\text { September 04/May-June 05/ } \\
\text { September 05/October 05) }\end{array}$ & $\begin{array}{c}{ }^{3} \mathrm{H}(\mathrm{TU}) \pm \text { Err } \\
\text { Mean Value } \\
\text { or Single } \\
\text { Datum }\end{array}$ & $\begin{array}{c}{ }^{3} \text { H(TU) Values } \\
\text { (March 04/June-July 04/ } \\
\text { September 04/May-June 05/ } \\
\text { September 05/October 05) }\end{array}$ \\
\hline 11 & 415 & 50 & -6.64 & $(-6.67 /-6.61 / \mathrm{ns} / \mathrm{ns} / \mathrm{ns})$ & -40.1 & $(-40.4 /-39.7 / \mathrm{ns} / \mathrm{ns} / \mathrm{ns})$ & $3.7 \pm 0.6$ & $(\mathrm{na} / 3.7 / \mathrm{ns} / \mathrm{ns} / \mathrm{ns})$ \\
\hline 12 & 545 & 80 & -6.60 & $(-6.62 /-6.58 / \mathrm{ns} / \mathrm{ns} / \mathrm{ns})$ & -39.8 & $(-39.2 /-40.4 / \mathrm{ns} / \mathrm{ns} / \mathrm{ns})$ & $4.2 \pm 0.7$ & $(\mathrm{na} / 4.2 / \mathrm{ns} / \mathrm{ns} / \mathrm{ns})$ \\
\hline 13 & 255 & 30 & -6.19 & $(-6.23 /-6.13 /-6.21 / \mathrm{ns} / \mathrm{ns})$ & -37.6 & $(-38.2 /-36.9 / \mathrm{na} / \mathrm{ns} / \mathrm{ns})$ & $3.7 \pm 0.6$ & $(\mathrm{na} / 3.6 / 3.7 / \mathrm{ns} / \mathrm{ns})$ \\
\hline 13bis & 190 & 5 & -6.18 & $(-6.18 / \mathrm{ns} / \mathrm{ns} / \mathrm{ns} / \mathrm{ns})$ & -37.7 & $(-37.7 / \mathrm{ns} / \mathrm{ns} / \mathrm{ns} / \mathrm{ns})$ & na & (na/ns/ns/ns/ns) \\
\hline 14 & 185 & 11 & -5.82 & $(-5.79 / \mathrm{ns} / \mathrm{ns} /-5.86 / \mathrm{ns})$ & -35.0 & $(-35.0 / \mathrm{ns} / \mathrm{ns} / \mathrm{na} / \mathrm{ns})$ & $5.9 \pm 0.7$ & $(5.9 / \mathrm{ns} / \mathrm{ns} / \mathrm{na} / \mathrm{ns})$ \\
\hline 15 & 60 & 40 & -5.46 & $(-5.51 /-5.40 / \mathrm{ns} / \mathrm{ns} / \mathrm{ns})$ & -32.6 & $(-33.1 /-32.0 / \mathrm{ns} / \mathrm{ns} / \mathrm{ns})$ & $6.6 \pm 0.7$ & $(\mathrm{na} / 6.6 / \mathrm{ns} / \mathrm{ns} / \mathrm{ns})$ \\
\hline 16 & 26 & 48 & -5.47 & $(-5.42 /-5.51 / \mathrm{ns} / \mathrm{ns} / \mathrm{ns})$ & -32.6 & $(-33.8 /-31.5 / \mathrm{ns} / \mathrm{ns} / \mathrm{ns})$ & $3.7 \pm 0.7$ & $(\mathrm{na} / 3.7 / \mathrm{ns} / \mathrm{ns} / \mathrm{ns})$ \\
\hline 19 & 58 & 85 & -5.81 & $(-5.81 / \mathrm{ns} / \mathrm{ns} / \mathrm{ns} / \mathrm{ns})$ & -36.2 & $(-36.2 / \mathrm{ns} / \mathrm{ns} / \mathrm{ns} / \mathrm{ns})$ & na & (na/ns/ns/ns/ns) \\
\hline 22 & 250 & 55 & -6.05 & $(-6.00 /-6.10 / \mathrm{ns} / \mathrm{ns} / \mathrm{ns})$ & -38.0 & $(-37.1 /-38.8 / \mathrm{ns} / \mathrm{ns} / \mathrm{ns})$ & $2.6 \pm 0.6$ & $(2.5 / 2.7 / \mathrm{ns} / \mathrm{ns} / \mathrm{ns})$ \\
\hline 23 & 400 & 66 & -6.51 & $(-6.52 /-6.46 /-6.56 / \mathrm{ns} / \mathrm{ns})$ & -39.2 & $(-38.5 /-39.9 / \mathrm{na} / \mathrm{ns} / \mathrm{ns})$ & na & (na/na/na/ns/ns) \\
\hline 24 & 365 & 54 & -5.75 & $(-5.78 /-5.72 / \mathrm{ns} / \mathrm{ns} / \mathrm{ns})$ & -34.2 & $(-35.2 /-33.2 / \mathrm{ns} / \mathrm{ns} / \mathrm{ns})$ & $4.3 \pm 0.7$ & (na/4.3/ns/ns/ns) \\
\hline 25 & 345 & 3 & -5.96 & $(-5.93 / \mathrm{ns} /-5.99 / \mathrm{ns} / \mathrm{ns})$ & -35.4 & $(-35.4 / \mathrm{ns} / \mathrm{na} / \mathrm{ns} / \mathrm{ns})$ & na & (na/ns/na/ns/ns) \\
\hline 26 & 120 & 60 & -5.82 & $(-5.79 /-5.78 /-5.89 / \mathrm{ns} / \mathrm{ns})$ & -35.6 & $(-35.3 /-35.9 / \mathrm{na} / \mathrm{ns} / \mathrm{ns})$ & $5.4 \pm 0.8$ & $(\mathrm{na} / 5.4 / \mathrm{na} / \mathrm{ns} / \mathrm{ns})$ \\
\hline 27 & 550 & 83 & -6.70 & $(-6.67 /-6.68 /-6.75 / \mathrm{ns} / \mathrm{ns})$ & -41.2 & $(-42.7 /-39.6 / \mathrm{na} / \mathrm{ns} / \mathrm{ns})$ & $3.7 \pm 0.7$ & $(\mathrm{na} / 3.9 / 3.5 / \mathrm{ns} / \mathrm{ns})$ \\
\hline 28 & 495 & 8 & -6.50 & (ns/-6.42/-6.59/ns/ns) & -38.7 & $(\mathrm{~ns} /-37.7 /-39.7 / \mathrm{ns} / \mathrm{ns})$ & $5.0 \pm 0.7$ & $(\mathrm{~ns} / 5.0 / \mathrm{na} / \mathrm{ns} / \mathrm{ns})$ \\
\hline 29 & 500 & 50 & -6.58 & $(\mathrm{~ns} /-6.55 /-6.61 / \mathrm{ns} / \mathrm{ns})$ & -39.0 & (ns/-39.0/na/ns/ns) & $2.4 \pm 0.5$ & $(\mathrm{~ns} / 2.5 / 2.3 / \mathrm{ns} / \mathrm{ns})$ \\
\hline 30 & 50 & 30 & -5.93 & $(\mathrm{~ns} /-5.92 /-5.94 / \mathrm{ns} / \mathrm{ns})$ & -35.4 & (ns/-35.4/na/ns/ns) & $4.6 \pm 0.7$ & $(\mathrm{~ns} / 4.1 / 5.0 / \mathrm{ns} / \mathrm{ns})$ \\
\hline 34 & 42 & 80 & -5.36 & $(\mathrm{~ns} /-5.28 /-5.44 / \mathrm{ns} / \mathrm{ns})$ & -32.8 & $(\mathrm{~ns} /-31.7 /-33.8 / \mathrm{ns} / \mathrm{ns})$ & $3.2 \pm 0.6$ & $(\mathrm{~ns} / 3.2 / \mathrm{na} / \mathrm{ns} / \mathrm{ns})$ \\
\hline 35 & 223 & 70 & -6.01 & $(\mathrm{~ns} /-6.09 / \mathrm{ns} /-5.94 / \mathrm{ns})$ & -36.7 & $(\mathrm{~ns} /-36.7 / \mathrm{ns} / \mathrm{na} / \mathrm{ns})$ & $5.6 \pm 0.7$ & $(\mathrm{~ns} / 5.6 / \mathrm{ns} / \mathrm{na} / \mathrm{ns})$ \\
\hline 36 & 185 & 32 & -6.06 & $(\mathrm{~ns} /-6.08 /-6.05 / \mathrm{ns} / \mathrm{ns})$ & -33.8 & $(\mathrm{~ns} /-33.8 / \mathrm{na} / \mathrm{ns} / \mathrm{ns})$ & $0.8 \pm 0.4$ & $(\mathrm{~ns} / 0.8 / 0.9 / \mathrm{ns} / \mathrm{ns})$ \\
\hline 37 & 285 & 80 & -5.91 & $(\mathrm{~ns} /-5.81 /-6.02 / \mathrm{ns} / \mathrm{ns})$ & -35.3 & $(\mathrm{~ns} /-35.3 / \mathrm{na} / \mathrm{ns} / \mathrm{ns})$ & $3.8 \pm 0.7$ & $(\mathrm{~ns} / 3.8 / \mathrm{na} / \mathrm{ns} / \mathrm{ns})$ \\
\hline
\end{tabular}


Table 2. Cont.

\begin{tabular}{|c|c|c|c|c|c|c|c|c|}
\hline $\begin{array}{l}\text { Sampled Wells } \\
\text { or } \\
\text { Streamwaters }\end{array}$ & $\begin{array}{c}\text { Altitudes of } \\
\text { Ground Level } \\
\text { (m a.s.l.) }\end{array}$ & $\begin{array}{l}\text { Depth of Well } \\
\text { (m) or } \\
\text { Name of } \\
\text { Streamwater }\end{array}$ & $\begin{array}{c}\delta^{18} \text { O\%o(VSMOW) } \\
\text { (Precision 0.10\%o) } \\
\text { Mean Value or } \\
\text { Single Datum } \\
\end{array}$ & $\begin{array}{c}\delta^{18} \text { O\% Values } \\
\text { (March 04/June-July 04/ } \\
\text { September 04/May-June 05/ } \\
\text { September 05/October 05) }\end{array}$ & $\begin{array}{c}\delta^{2} H \% \text { (VSMOW) } \\
\text { (Precision 1.5\%o) } \\
\text { Mean Value or } \\
\text { Single Datum } \\
\end{array}$ & $\begin{array}{c}\delta^{2} \text { H\%o Values } \\
\text { (March 04/June-July 04/ } \\
\text { September 04/May-June 05/ } \\
\text { September 05/October 05) }\end{array}$ & $\begin{array}{c}{ }^{3} \mathrm{H}(\mathrm{TU}) \pm \text { Err } \\
\text { Mean Value } \\
\text { or Single } \\
\text { Datum } \\
\end{array}$ & $\begin{array}{c}{ }^{3} \mathrm{H}(\mathrm{TU}) \text { Values } \\
\text { (March 04/June-July 04/ } \\
\text { September 04/May-June 05/ } \\
\text { September 05/October 05) }\end{array}$ \\
\hline 38 & 80 & 5 & -5.56 & $(\mathrm{~ns} / \mathrm{ns} /-5.56 / \mathrm{ns} / \mathrm{ns})$ & -34.7 & $(\mathrm{~ns} / \mathrm{ns} /-34.7 / \mathrm{ns} / \mathrm{ns})$ & na & $(\mathrm{ns} / \mathrm{ns} / \mathrm{na} / \mathrm{ns} / \mathrm{ns})$ \\
\hline 41 & 49 & 40 & -5.99 & $(\mathrm{~ns} / \mathrm{ns} /-6.02 /-6.07 /-5.89)$ & -37.6 & $(\mathrm{~ns} / \mathrm{ns} /-37.6 / \mathrm{na} / \mathrm{na})$ & na & (ns/ns/na/na/na) \\
\hline 42 & 49 & 35 & -5.97 & $(\mathrm{~ns} / \mathrm{ns} /-5.97 / \mathrm{ns} / \mathrm{ns})$ & -36.5 & $(\mathrm{~ns} / \mathrm{ns} /-36.5 / \mathrm{ns} / \mathrm{ns})$ & na & $(\mathrm{ns} / \mathrm{ns} / \mathrm{na} / \mathrm{ns} / \mathrm{ns})$ \\
\hline 45 & 346 & 40 & -5.90 & $(\mathrm{~ns} / \mathrm{ns} /-5.90 / \mathrm{ns} / \mathrm{ns})$ & -36.9 & $(\mathrm{~ns} / \mathrm{ns} /-36.9 / \mathrm{ns} / \mathrm{ns})$ & $5.3 \pm 0.7$ & $(\mathrm{~ns} / \mathrm{ns} / 5.3 / \mathrm{ns} / \mathrm{ns})$ \\
\hline 49 & 360 & 4 & -5.70 & $(\mathrm{~ns} / \mathrm{ns} / \mathrm{ns} /-5.70 / \mathrm{ns})$ & -35.7 & $(\mathrm{~ns} / \mathrm{ns} / \mathrm{ns} /-35.7 / \mathrm{ns})$ & $4.1 \pm 0.6$ & $(\mathrm{~ns} / \mathrm{ns} / \mathrm{ns} / 4.1 / \mathrm{ns})$ \\
\hline 50 & 328 & 38 & -6.15 & $(\mathrm{~ns} / \mathrm{ns} / \mathrm{ns} /-6.15 / \mathrm{ns})$ & -37.8 & $(\mathrm{~ns} / \mathrm{ns} / \mathrm{ns} /-37.8 / \mathrm{ns})$ & na & $(\mathrm{ns} / \mathrm{ns} / \mathrm{ns} / \mathrm{na} / \mathrm{ns})$ \\
\hline 51 & 38 & 50 & -5.97 & $(\mathrm{~ns} / \mathrm{ns} / \mathrm{ns} /-5.97 / \mathrm{ns})$ & -37.7 & $(\mathrm{~ns} / \mathrm{ns} / \mathrm{ns} /-37.7 / \mathrm{ns})$ & na & $(\mathrm{ns} / \mathrm{ns} / \mathrm{ns} / \mathrm{na} / \mathrm{ns})$ \\
\hline 52 & 218 & 60 & -6.03 & $(\mathrm{~ns} / \mathrm{ns} / \mathrm{ns} /-6.03 / \mathrm{ns})$ & -36.6 & $(\mathrm{~ns} / \mathrm{ns} / \mathrm{ns} /-36.6 / \mathrm{ns})$ & na & $(\mathrm{ns} / \mathrm{ns} / \mathrm{ns} / \mathrm{na} / \mathrm{ns})$ \\
\hline 56 & 355 & 50 & -5.93 & $(\mathrm{~ns} / \mathrm{ns} / \mathrm{ns} /-5.93 / \mathrm{ns})$ & -36.5 & $(\mathrm{~ns} / \mathrm{ns} / \mathrm{ns} /-36.5 / \mathrm{ns})$ & na & (ns/ns/ns/na/ns) \\
\hline 59 & 52 & 40 & -5.55 & (ns/ns/ns/ns/-5.55) & -33.2 & $(\mathrm{~ns} / \mathrm{ns} / \mathrm{ns} / \mathrm{ns} /-33.2)$ & na & (ns/ns/ns/ns/na) \\
\hline 39 & 53 & Patrignone & -5.53 & $(\mathrm{~ns} / \mathrm{ns} /-5.80 / \mathrm{ns} /-5.27)$ & -34.1 & $(\mathrm{~ns} / \mathrm{ns} /-34.1 / \mathrm{ns} / \mathrm{na})$ & $4.5 \pm 0.6$ & $(\mathrm{~ns} / \mathrm{ns} / 4.5 / \mathrm{ns} / \mathrm{na})$ \\
\hline 63 & 72 & Castione & -5.84 & $(\mathrm{~ns} / \mathrm{ns} / \mathrm{ns} / \mathrm{ns} /-5.84)$ & -34.9 & $(\mathrm{~ns} / \mathrm{ns} / \mathrm{ns} / \mathrm{ns} /-34.9)$ & na & $(\mathrm{ns} / \mathrm{ns} / \mathrm{ns} / \mathrm{ns} / \mathrm{na})$ \\
\hline
\end{tabular}

Notes: ns: not sampled; na: not analyzed. 
Figure 7. Thematic map of the $\delta^{18} \mathrm{O} \%$ values.

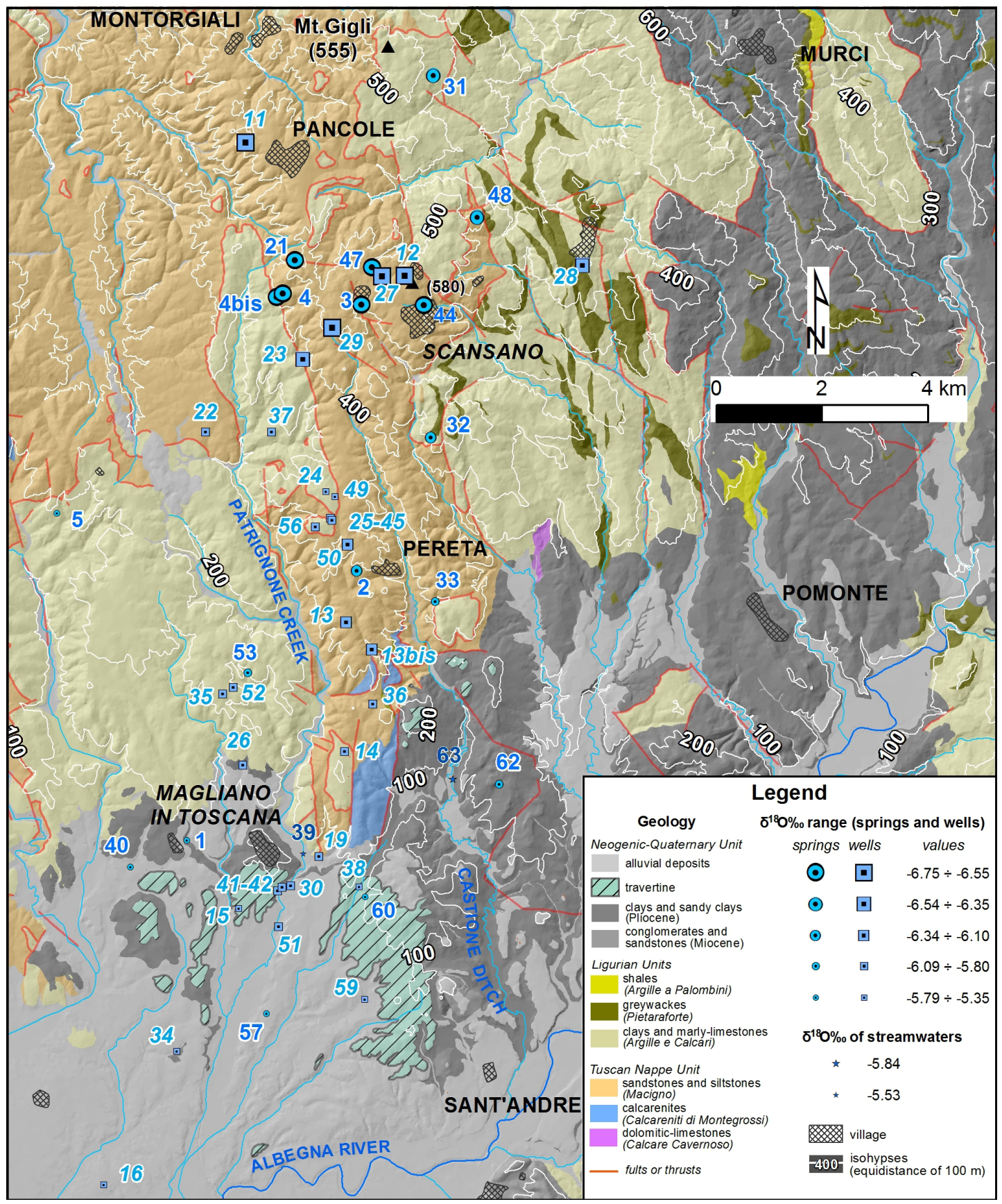

Downstream of Magliano in Toscana, where the alluvial system dominates, very different values of $\delta^{18} \mathrm{O}$ were detected in wells that are close to each other and have a similar depth. The most evident case regards the well 15 , whose average value is $-5.4 \%$, and the wells $30,41,42,51$, which are characterized by values from $-5.9 \%$ to $-6.0 \%$ (Figures 6 and 7 ). The latter values are congruent with those detected in the sandstones groundwater flow, thus suggesting a likely groundwater transfer from the sandy aquifer toward the alluvial aquifer system. This is in agreement with the distribution of the wells, since the $30,41,42,52$ are in front of the zone in which the alluvial sediments overlap the sandstones, contrarily to the 15 which is westward. The possibility that the Patrignone creek, given the proximity, affects the isotopic features of the wells $30,41,42,51$, seems instead to be unlikely, 
because in contrast with the homogeneity and stability observed in the wells water values the streamwater showed a consistent $\delta^{18} \mathrm{O}$ variability, between $-5.3 \%$ and $-5.8 \%$.

An evaluation of the recharge average altitudes for the groundwater flowing in the study area can be performed by means of the diagram in Figure 8 . The latter takes into account the "infiltration average altitudes $/ \delta^{18} \mathrm{O}$ values" relationship, previously achieved (Figure 4), and moreover the average $\delta^{18} \mathrm{O}$ values of all wells and of the springs which denoted a draining of groundwater not exclusively fed by local infiltration water (to insert the wells and springs points into the diagram the altitudes of ground level were considered).

Figure 8. Comparison between the "infiltration average altitudes $/ \delta^{18} \mathrm{O}$ values" relationship (1) and the $\delta^{18} \mathrm{O} \%$ values achieved in the Scansano-Magliano in Toscana zone from wells and springs draining sandstones aquifer ( 3 and $\mathbf{4}$, respectively), and from wells draining the other hydrogeological complexes (2).

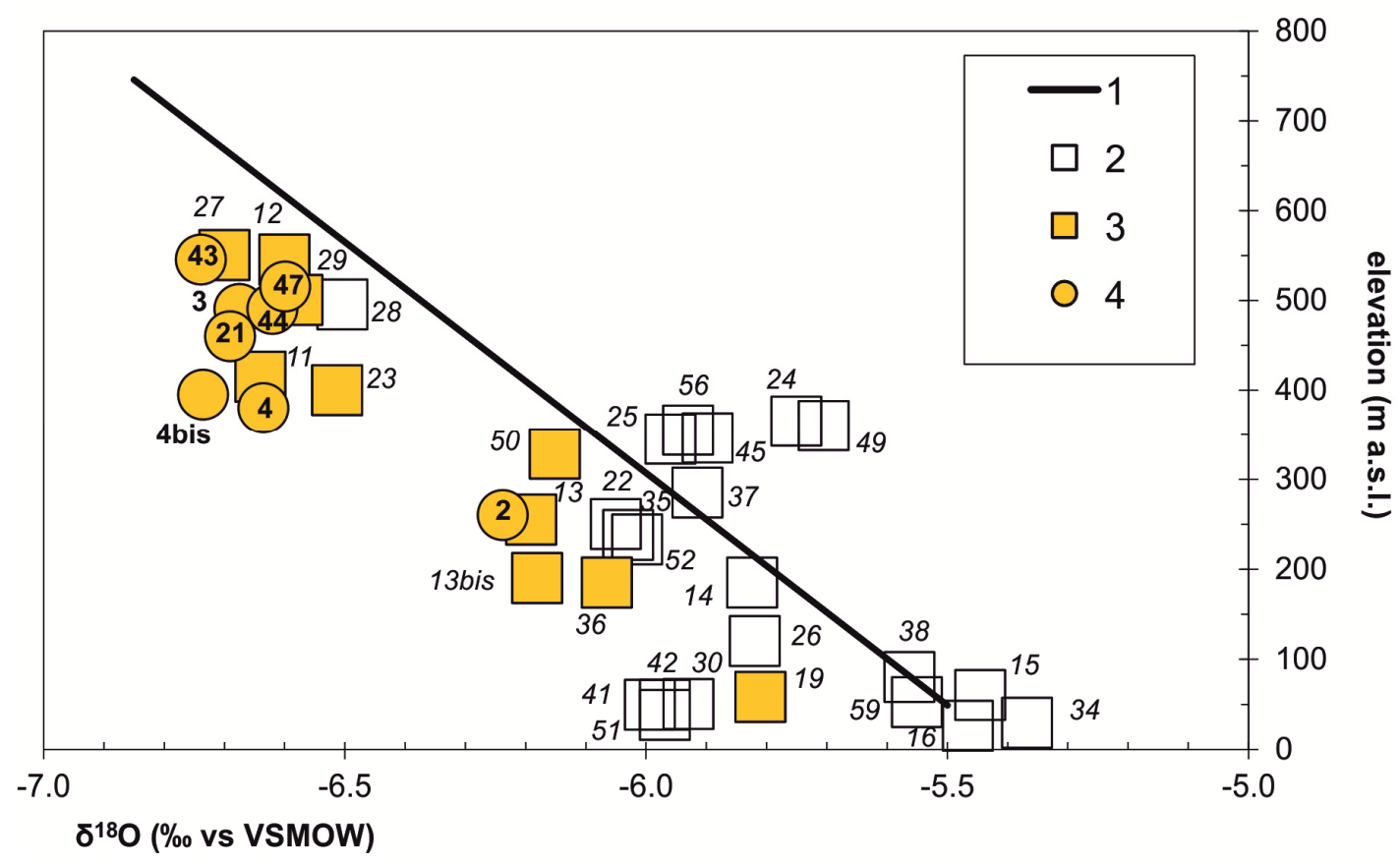

For the springs $(3,4,4 \mathrm{bis}, 21,44,47)$ and wells $(11,12,23,27,29)$ that drain groundwater from sandstones in the Scansano-Pancole zone, a recharge average altitude in the range 600-700 m (a.s.1.) is assessable. Considering that this zone mainly develops between 450 and $550 \mathrm{~m}$ (a.s.1.), and that its highest altitude is about $580 \mathrm{~m}$ (a.s.1.) (Figures 1 and 7), the presence of a significant regional groundwater component is required to justify the above mentioned range of feeding average altitudes. Indeed, in the surrounding area the nearest zones with altitudes of 600-700 m a.s.1. (and higher ones, necessarily involved to obtain such range of average values) are present toward NE and at more than $13 \mathrm{~km}$ from Scansano.

The water sampled in the Pereta zone (2, 13, 13bis, 36, 50), and again representative of the sandstones aquifer, have isotopic features that indicate the range 350-450 m a.s.l. as average altitudes of feeding. These elevations are detectable between Pereta and Scansano at about 4-6 km from the sampling sites; at any rate, the groundwater flow paths may also be considered more extended, because, being average elevations, a feeding from altitudes higher than $450 \mathrm{~m}$ a.s.1., such as that of the 
Scansano zone, is likely. A probable hypothesis is that the groundwater of the Scansano zone represents the starting point of a flow path that develops with continuity southward, and whose $\delta^{18} \mathrm{O}$ values are influenced by the $\delta^{18} \mathrm{O}$ values of the water that infiltrates into the sandstones aquifer at the minor altitudes encountered moving in this direction. At least up to Magliano in Toscana, such sandstones groundwater flow system and its transfer in the alluvial deposits are verified by isotopic features of the wells 19, 30, 41, 42, 51. In fact, as highlighted in Figure 8, recharge average altitudes of about 200-300 m a.s.l. are assessable for these water points, and they are consistent with an involvement of the zones that develop northward from Pereta. All other points plotted into the diagram, and representative of groundwater hosted in marly, shelly or alluvial complexes, denote a recharge from average altitudes that are similar to the elevation of the zones in which they are located, thus suggesting that these groundwater flow systems have generally a local importance. Five wells (24, $25,45,49,56)$ even showed $\delta^{18} \mathrm{O}$ values apparently incompatible with the regression line in the Figure 8 , because based on the same line a recharge average altitude below the ground level is achieved (also taking into account the bottom of the well the incongruence persists). These wells are all located in a restricted area near Pereta (Figure 7), so the verified behavior seems to be connected to local causes. Although with the available data it is not possible to reach a conclusion, a probable influence of hydro-structural conditions on the local groundwater isotopic features can be supposed. The marly complex, in which the wells tap groundwater, is here interested by a wide fractured zone between two main sub-vertical faults, for the presence of the nearby tectonic contact with the sandstones [24]. High rainfall infiltration rates can so occur and locally lead to an isotopic variability in groundwater during the hydrologic year. Since the mentioned wells were sampled only once or twice, their isotopic values in such hypothesis would not be representative of the average annual values in local groundwater and therefore not even of the average altitudes of the recharge area.

In the framework above delineated, Figure 6 might be also viewed as representative of a mixing in which regional groundwaters and shallower, locally recharged groundwaters are involved. This would suggest that regional water mixes upwards into the shallower systems. However, further hydrogeological investigation is required to resolve the appropriate conceptual model.

Tritium was analyzed on 19 of the 31 wells (Table 2), and where the analyses were twice performed the contents have been stable over time. In order to achieve preliminary indications on the average age of the well water, the results of analysis are compared in Figure 9 to the annual average content of rainfall, previously depleted by means of the decay law. Most of the well water is characterized by values that are congruent with those of the rain of the last 4-5 years, anyway such values may be also affected by water infiltrated in the period 1980-2000.

The wells 15, 22, 29, 36 are distinguished from other ones. The water of the well 15 (6.6 TU) seems to be characterized by an average age of 25 or more years, which may be due to low-permeability conditions for a local prevalence of clayey sediments in the alluvial system. The tritium contents of 2.6, 2.4 and $0.8 \mathrm{TU}$, detected for the other three wells, are compatible with average residence times of 50 or more years. Since on the base of $\delta^{18} \mathrm{O}$ values these water wells belong to sandstones groundwater flow system and most of water points of this system showed shorter residence time, local conditions of low-permeability in this aquifer can be supposed. 
Figure 9. Tritium values of the well water in comparison to tritium values of precipitations.

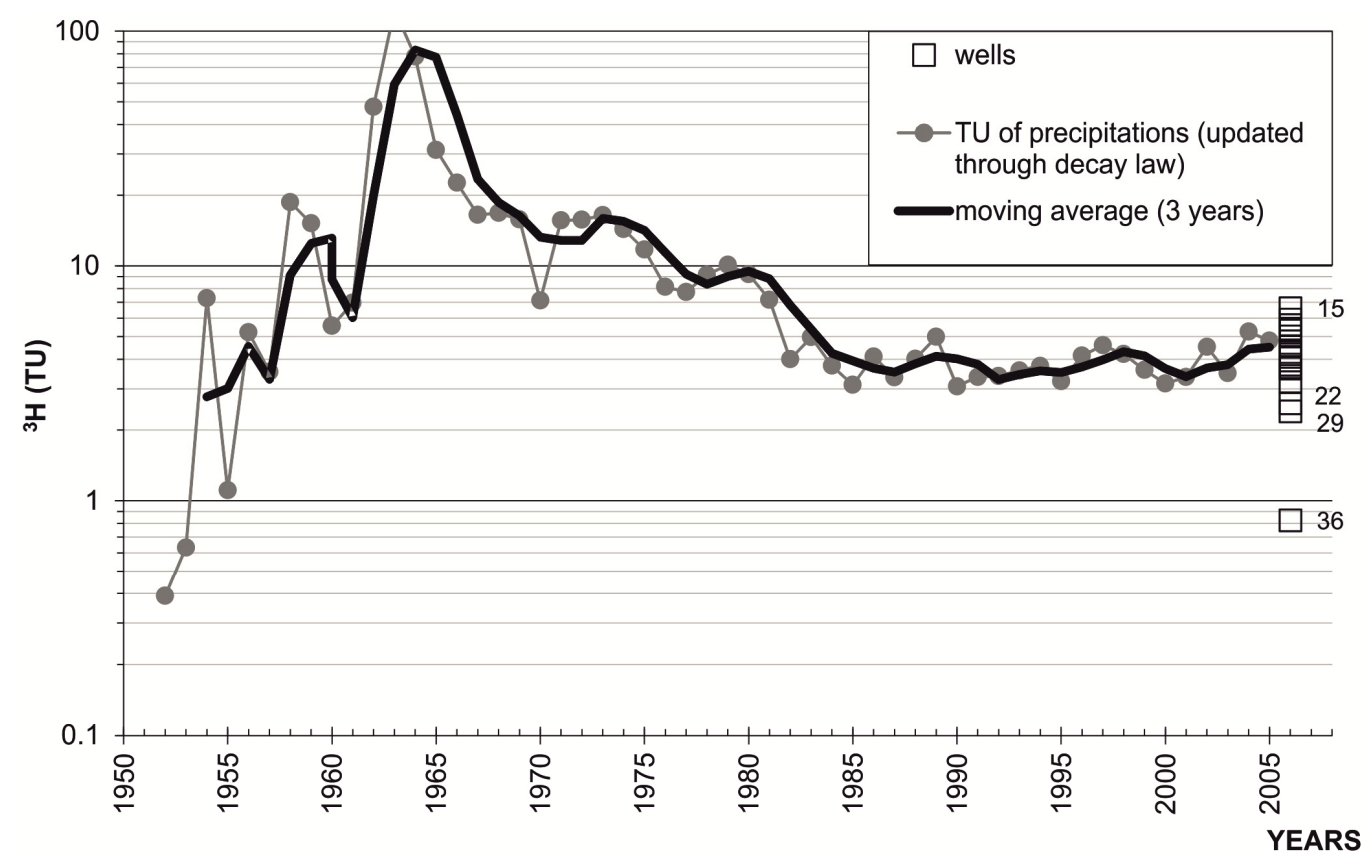

\subsection{Preliminary Elaboration of the Conceptual Hydrogeological Model}

Previous discussion has highlighted as in the Scansano zone the sandstones aquifer receives, in addition to local infiltration water, an input from regional groundwater. Presuming mixing of these two components as end-members, their mixing can be translated into the following equations, which refer to $\delta^{18} \mathrm{O}$ and ${ }^{3} \mathrm{H}$ parameters:

$$
\begin{gathered}
-6.4 \times(1-R)+X \times R=-6.6 \\
5 \times(1-R)+Y \times R=4
\end{gathered}
$$

Where,

- $-6.4(\%)$ is the value of $\delta^{18} \mathrm{O}$ for the local water. It corresponds to the approximation to first decimal place of the value $\left(-6.37 \%\right.$ ) achieved from the "infiltration average altitudes $/ \delta^{18} \mathrm{O}$ values" relationship, considering the average altitude of the Scansano zone (500 $\mathrm{m}$ a.s.1.). At this value of altitude, the upper and lower limit of the $95 \%$ confidence interval of regression line in Figure 4 are $-6.32 \%$ and $-6.42 \%$, respectively;

- $-6.6(\%)$ is the value of $\delta^{18} \mathrm{O}$ for the result of the mixing. It is the approximation to first decimal place of the value $(-6.64 \%)$ achieved by the average of the data of the twelve water points (wells and springs) which are representative of such mixing. The standard deviation " $\sigma$ " of the data set is 0.07 ;

- 5 (TU) is the value of ${ }^{3} \mathrm{H}$ for the local water. It corresponds to the approximation of the average value (5.1 TU; $\sigma=0.4$ ) of the tritium annual data of rainfall for the years 2004 and 2005 (just before the study period);

- 4 (TU) is the value of ${ }^{3} \mathrm{H}$ for the result of the mixing. It is the approximation of the value (3.8 TU) achieved by the average of the available data for the water points which are representative of the mixing (number of points $=4 ; \sigma=0.3$ ); 
- $\quad(1-R)$ and $R$ are, respectively, the percentages of local and regional groundwater involved in the mixing;

- $\quad X$ and $\mathrm{Y}$ are, respectively, the $\delta^{18} \mathrm{O}$ and ${ }^{3} \mathrm{H}$ values of the regional groundwater.

It should be noted that the differences between the isotopic values inserted in the equations for the local water and for the mixing result are of the order of the analytical error (for both $\delta^{18} \mathrm{O}$ and ${ }^{3} \mathrm{H}$ ). Even so, taking into account the performed approximations, the $\sigma$ values and the $95 \%$ confidence interval above mentioned, it is possible to state that such differences are significant.

Solving the Equations (1) and (2) for $\mathrm{R}$, and after simplifications, the following equation is achieved:

$$
X=-7.4+0.2 Y
$$

Taking into account the ${ }^{3} \mathrm{H}$ values of the local input and of the mixing result, the ${ }^{3} \mathrm{H}$ value in regional groundwater is necessarily less than $4.0 \mathrm{TU}$. A value in the range 0-3 TU can be considered realistic, given that:

- based on the morphology, the average altitude achieved from the $\delta^{18} \mathrm{O}$ value of the mixing indicates as the regional groundwater flow is activated more than $13 \mathrm{~km}$ from Scansano. Especially in such hydrostructural context, a resident time of several tens of years is consequently probable, and in this case the range 0-3 TU is consistent with the tritium curve showed in Figure 9;

- as showed by the evolution of the $\delta^{18} \mathrm{O}$ values occurring in groundwater along the Scansano-Magliano in Toscana ridge, a significant rate of local infiltration in sandstone occurs, consequently to modify the value from 5 TU (local groundwater) up to $4 \mathrm{TU}$ (mixing result) a tritium content abundantly lower than $4 \mathrm{TU}$ is likely for regional groundwater.

Assuming that $Y$ in Equation (3) is 0 or $3 \mathrm{TU}$, alternatively, we obtain $\delta^{18} \mathrm{O}$ values of $-6.8 \%$ and $-7.4 \%$, which indicate recharge average altitudes for the regional groundwater within the range 700-1000 m (a.s.1.); at these two extreme conditions of mixing, percentages of regional groundwater (R) of $50 \%$ and $20 \%$ are respectively achieved. Such average altitudes, if crossed with the morphologic and hydrostructural features of the region, suggest that the main recharge area for regional groundwater could develop among Mt. Labbro, Rocchette, Catabbio and Petricci, in which calcarenites and limestone outcrop (Figure 1). Indeed, the volcanites of Mt. Amiata (altitudes up to $1700 \mathrm{~m}$ a.s.1.) are not involved in regional flow because for this aquifer the infiltration is completely balanced by perennial yield [33]. Thus, in agreement with the general low permeability of the lithologies, important contributes from the zone between Scansano and Roccalbegna (Figure 1) may also be excluded, because in the absence of input from Mt. Amiata they would lead to lower recharge average altitudes than 700-1000 m (a.s.1.).

A preliminary conceptual model for the groundwater flow in the sandstone aquifer can be at this point proposed (Figure 10):

- regional groundwater, mainly fed from the Mt. Labbro-Rocchette-Catabbio-Petricci zone, reaches the sandstones aquifer in the Scansano zone by means of an upflow in the fault 
systems, and mixes with the local infiltration water. An uprising of regional groundwater along such fault systems was also suggested by Francese et al. (2009) [24];

- groundwater resources resulting from such mixing are partially drained by springs and withdrawn by wells, and partially take part in a groundwater flow system that with continuity develops within sandstones at least up to Magliano in Toscana, where a groundwater transfer toward the alluvial system also occurs.

Figure 10. Groundwater flow conceptual model: (a) simplified map of the hydrogeological complexes and location of the main recharge area supposed for regional groundwater; (b) hydrogeological cross section showing hypothesized flow lines of the components involved in the groundwater flow.
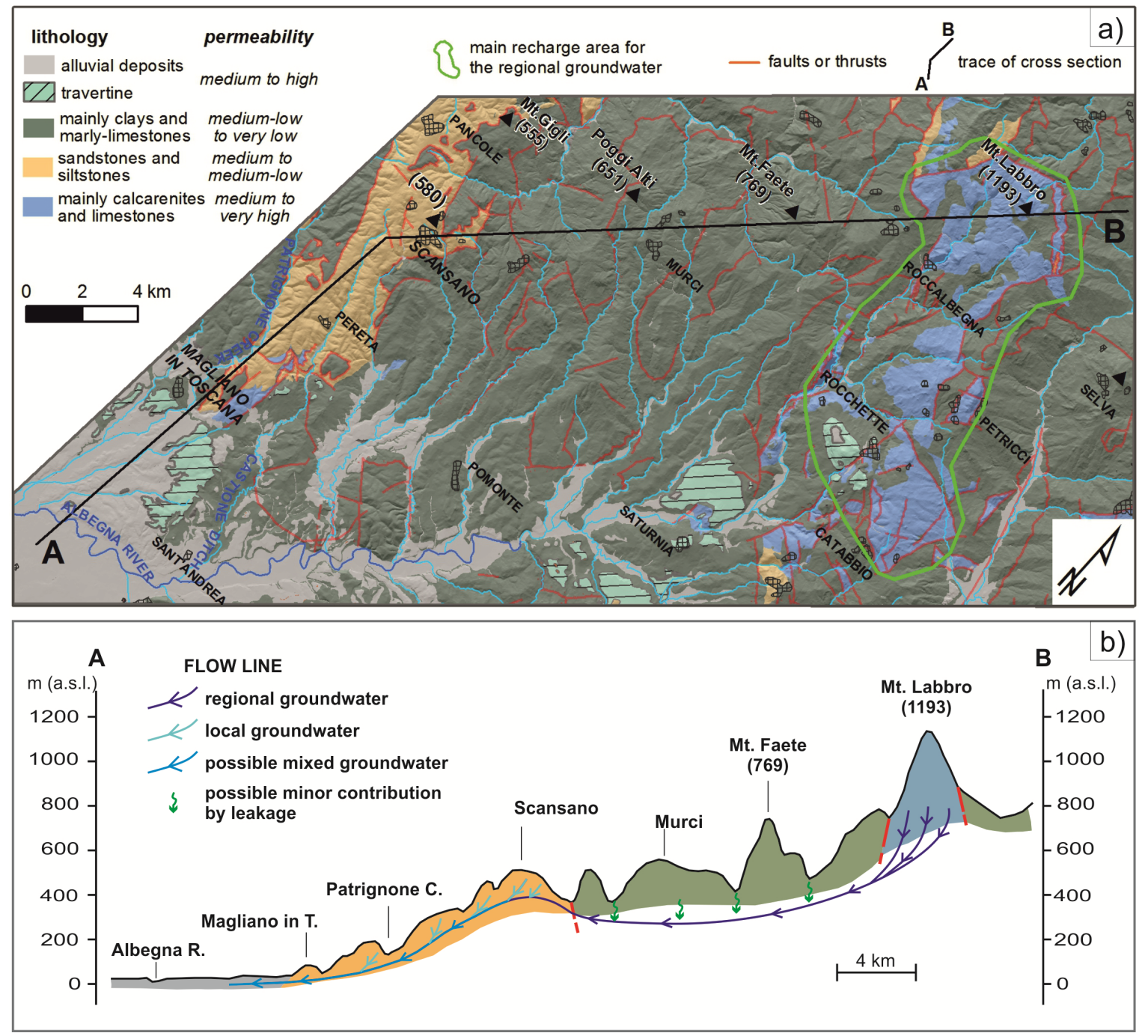

\section{Conclusions}

The water isotopes, which were analyzed in groundwater, allowed us to define the groundwater framework in the area of Scansano-Magliano in Toscana ridge and to propose a conceptual hydrogeological model. Thanks to a detailed isotopic characterization of infiltration water, which was achieved by analyzing minor springs opportunely selected, the data of groundwater from wells and 
major springs highlighted the presence of a main groundwater flow system. The latter develops with continuity within the sandstones complex for more than $12 \mathrm{~km}$, moving from Scansano up to Magliano in Toscana, where at least partially it transfers groundwater to the alluvial aquifer system. In the highest part of such groundwater system, nearby Scansano, the isotopes suggest a mixing process that involves local infiltration water and regional groundwater, whose recharge area, on the base of $\delta^{18} \mathrm{O}$ and ${ }^{3} \mathrm{H}$ mass balances, seems mainly develops on the calcarenite and limestones outcropping in the Mt. Labbro-Rocchette-Catabbio-Petricci zone, more than $15 \mathrm{~km}$ away from Scansano.

The results discussed in this work underpin that water isotopes help groundwater flow understanding, especially in fractured aquifer for which the application of conventional methodology is not always effortless. In the specific case, the isotopic tools pointed out as the sandstone aquifer of the Scansano-Magliano in Toscana ridge may be a strategic and alternative resource for water supplying, given the overexploitation and contamination of the nearby alluvial aquifers. In this context, the sandstone aquifer, in addition to representing an important water source for the isolated villages that exist on the ridge, might also be tapped to improve, both in quality and quantity, the water supplying for the villages in the nearby coastal plain. Indeed, in the latter, especially during the summer period, the high water demand linked to the touristic vocation of the region leads to an excessive drawdown in the local groundwater body with consequent seawater intrusion occurrence and worsening of water quality.

Finally, the achieved results encourage and promote more detailed surveys of the chemical, geophysical, and hydrodynamic type, which should be aimed at defining what zones of the sandy aquifer are more suitable for groundwater exploitation.

\section{Acknowledgments}

The authors wish to thank Sandra Trifiro', Enrico Calvi, Elisa Ferrari, Maurizio Catania, Caterina Giorgi of the IGG-CNR for their precious work in field sampling and laboratory analyzing. The authors thank the editor and two anonymous reviewers for their useful comments, which helped us to improve the manuscript. This research was financially supported by a grant of AATO6-Ombrone.

\section{Author Contributions}

Both Authors planned and carried out this research, and cooperated in the elaboration and interpretation of the achieved data. The paper was prepared under the direction of Marco Doveri.

\section{Conflicts of Interest}

The authors declare no conflict of interest.

\section{References}

1. Panichi, C.; Gonfiantini, R. Environmental isotopes in geothermal studies. Geothermics 1978, 6, $143-161$. 
2. Fontes, J.C. Environmental Isotopes in Groundwater Hydrology. In Handbook of Environmental Isotope Geochemistry, 1st ed.; Fritz, P., Fontes, J.C., Eds.; Elsevier Scientific Publishing: Amsterdam, The Netherlands, 1980; Volume 1, pp. 75-134.

3. Yurtsever, Y.; Gat, J.R. Atmospheric waters. In Stable Isotope Hydrology (Deuterium and Oxygen-18 in the Water Cycle), 1st ed.; Technical Reports 210; Gat, J.R., Gonfiantini, R., Eds.; International Atomic Energy Agency (IAEA): Vienna, Austria, 1981; pp. 103-142.

4. Clark, I.; Fritz, P.; Precipitation. In Environmental Isotopes in Hydrogeology, 1st ed.; Stein, J., Starkweather, A.W., Eds.; Lewis Publishers CRC Press: Boca Raton, FL, USA, 1997; pp. 63-78.

5. Wood, W.W.; Sanford, W.E. Chemical and isotopic methods for quantifying groundwater recharge in a regional, semiarid environment. Ground Water 1995, 33, 458-468.

6. Mohammad, Z.I. Application of environmental isotopes in storm-discharge analysis of two contrasting stream channel in a watershed. Water Res. 1998, 32, 2959-2968.

7. Marfia, A.M.; Krishnamurthy, R.V.; Atekwana, E.A.; Panton, W.F. Isotopic and geochemical evolution of ground and surface waters in a karst dominated geological setting: A case study from Belize, Central America. Appl. Geochem. 2004, 19, 937-946.

8. Doveri, M.; Menichini, M.; Cerrina Feroni, A. Stable water isotopes as fundamental tool in karst aquifer studies: Some results from isotopic applications in the Apuan Alps carbonatic complexes (NW Tuscany). Italian J. Eng. Geol. Environ. 2013, 1, 33-50.

9. Consorzio Lamma. Territorio: Geologia, Carta Geologica Regionale 1:10,000. Available online: http://www.lamma.rete.toscana.it/territorio/geologia (accessed on 15 January 2013).

10. Servizio Idrologico Regionale: Archivio dati. Available online: http://www.sir.toscana.it (accessed on 21 March 2013).

11. Vittorini, S. Ricerche sul clima della Toscana in base all'evapotraspirazione potenziale e al bilancio idrico. Rivista Geografica Italiana 1972, 1, 1-30.

12. Boccaletti, M.; Elter, P.; Guazzone, G. Plate tectonics models for the development of Western Alps and Northern Apennines. Nature 1971, 234, 108-111.

13. Boccaletti, M.; Coli, M.; Decandia, F.A.; Giannini, E.; Lazzarotto, A. Evoluzione dell'Appennino settentrionale secondo un nuovo modello strutturale. Memorie della Società Geologica Italiana 1981, 21, 359-373.

14. Molli, G. Northern Apennine-Corsica orogenic system: An updated review. Geol. Soc. Lond. Spec. Publ. 2008, 298, 413-442.

15. Mongelli, F.; Zito, G. Flusso di calore nella regione Toscana. Studi Geologici Camerti 1991, 1, 91-98.

16. Elter, P. L'ensemble ligure. Bulletin de la Société Géologique de France 1975, 17, 984-997.

17. Marroni, M.; Treves, B. Hidden terranes in the northern Apennines, Italy: A record of Late Cretaceous-Oligocene transpressional tectonics. J. Geol. 1998, 106, 149-162.

18. Nirta, G.; Pandeli, E.; Principi, G.; Bertini, G.; Cipriani, N. The Ligurian Units of Southern Tuscany. Bollettino della Società Geologica Italiana 2005, 3, 29-54.

19. Jolivet, L.; Daniel, J.M.; Truffert, C.; Goffé, B. Exhumation of deep crustal metamorphic rocks and crustal extension in back-arc regions. Lithos 1994, 33, 3-30. 
20. Carmignani, L.; Decandia, F.A.; Disperati, L.; Fantozzi, P.L.; Lazzarotto, A.; Liotta, D.; Oggiano, G. Relationships between the Sardinia-Corsica-Provencal Domain and the Northern Apennines. Terra Nova 1995, 7, 128-137.

21. Brunet, C.; Monié, P.; Jolivet, L.; Cadet, J.P. Migration of compression and extension in the Tyrrhenian Sea: Insights from 40Ar/39Ar ages on micas along a transect from Corsica to Tuscany. Tectonophysics 2000, 321, 127-155.

22. Carmignani, L.; Kligfield, R. Crustal extension in the Northern Apennines: Transition from compression to extension in the Alpi Apuane core complex. Tectonics 1990, 9, 1275-1303.

23. Brogi, A.; Lazzarotto, A.; Liotta, D.; Ranalli, G. Extensional shear zones as imaged by reflection seismic lines: The Larderello geothermal field (Central Italy). Tectonophysics 2003, 363, 127-139.

24. Francese, R.; Mazzarini, F.; Bistacchi, A.; Morelli, G.; Pasquarè, G.; Praticelli, N.; Robain, H.; Wardell, N.; Zaja, A. A structural and geophysical approach to the study of fractured aquifers in the Scansano-Magliano in Toscana Ridge, southern Tuscany, Italy. Hydrogeol. J. 2009, 17, 1233-1246.

25. Fritz, P.; Fontes, J.C. Introduction. In Handbook of Environmental Isotope Geochemistry, 1st ed.; Fritz, P., Fontes, J.C., Eds.; Elsevier Scientific Publishing: Amsterdam, The Netherlands, 1980; Volume 1, pp. 1-19.

26. Epstein, S.; Mayeda, T. Variation of $\mathrm{O}^{18}$ content of waters from natural sources. Geochim. Cosmochim. Acta 1953, 4, 213-224.

27. Coleman, M.L.; Shepherd, T.J.; Durham, J.J.; Rouse, J.E.; Moore, G.R. Reduction of water with zinc for hydrogen isotope analysis. Anal. Chem. 1982, 54, 993-995.

28. Longinelli, A.; Selmo, E. Isotopic composition of precipitation in Italy: A first overall map. J. Hydrogeol. 2003, 270, 75-88.

29. Mussi, M.; Leone, G.; Nardi, I. Isotopic geochemistry of natural water from the Alpi Apuane-Garfagnana area, Northern Tuscany, Italy. Mineral. Petrogr. Acta 1998, 41, 163-178.

30. Doveri, M.; Nisi, B.; Cerrina Feroni, A.; Ellero, A.; Menichini, M.; Lelli, M.; Masetti, G.; Da Prato, S.; Principe, C.; Raco, B. Geological, hydrodynamic and geochemical features of the volcanic aquifer of Mt. Amiata (Tuscany, central Italy): An overview. Acta Vulcanol. 2011-2012, 23-24, 51-72.

31. International Atomic Energy Agency and World Meteorological Organization. Global Network of Isotopes in Precipitation: The GNIP Database. Available online: http://isohis.iaea.org (accessed on 24 November 2005).

32. Doveri, M.; Leone, G.; Mussi, M.; Zanchetta, G. Composizione isotopica di acque ipogee nell'Antro del Corchia (Alpi Apuane, Toscana nord-occidentale). Memorie dell'Istituto Italiano di Speleologia Serie 2 2005, 18, 119-132.

33. Barazzuoli, P.; Bosco, G.; Nante, N.; Rappuoli, D.; Salleolini, M. The aquifer of Mount Amiata: Evaluation of the perennial yield and its quality. Memorie della Società Geologica Italiana 1994, 48, 825-832.

34. Craig, H. Isotopic Variation in meteoric waters. Science 1961, 133, 1702.

35. Gat, J.R.; Carmi, I. Evolution of the isotopic composition of atmosferic waters in the Mediterranean area. J. Geophys. Res. 1970, 75, 3039-3048. 
36. Minissale, A.; Magro, G.; Vaselli, O.; Verrucchi, C.; Perticone, I. Geochemistry of water and gas discharges from the Mt. Amiata silic complex and surrounding areas (central Italy). J. Volcanol. Geotherm. Res. 1997, 79, 223-251.

37. Hauser, S.; Dongarrà, G.; Favara, R.; Longinelli, A. Composizione isotopica delle piogge in Sicilia. Riferimenti di base per studi idrogeologici e relazioni con altre aree mediterranee. Rendiconti della Società Italiana di Mineralogia e Petrologia 1980, 36, 671-680.

38. Leone, G.; Mussi, M. Gli isotopi ambientali nelle acque di sorgenti e pozzi e nelle emergenze sulfuree sottomarine di Capo Palinuro, Salerno. Geologia tecnica e ambientale 2004, 3, 35-55.

39. Celati, R.; Grassi, S.; D'Amore, F.; Marcolini, L. The low temperature hydrothermal system of Campiglia, Tuscany (Italy): A geochemical approach. Geothermics 1991, 20, 67-81.

(C) 2014 by the authors; licensee MDPI, Basel, Switzerland. This article is an open access article distributed under the terms and conditions of the Creative Commons Attribution license (http://creativecommons.org/licenses/by/3.0/). 